Universidade de São Paulo

Faculdade de Medicina de Ribeirão Preto

\title{
2021
}

Análise biomecânica do pé

de corredores recreacionais assintomáticos

para lesões musculoesqueléticas

e de corredores com dor femoropatelar
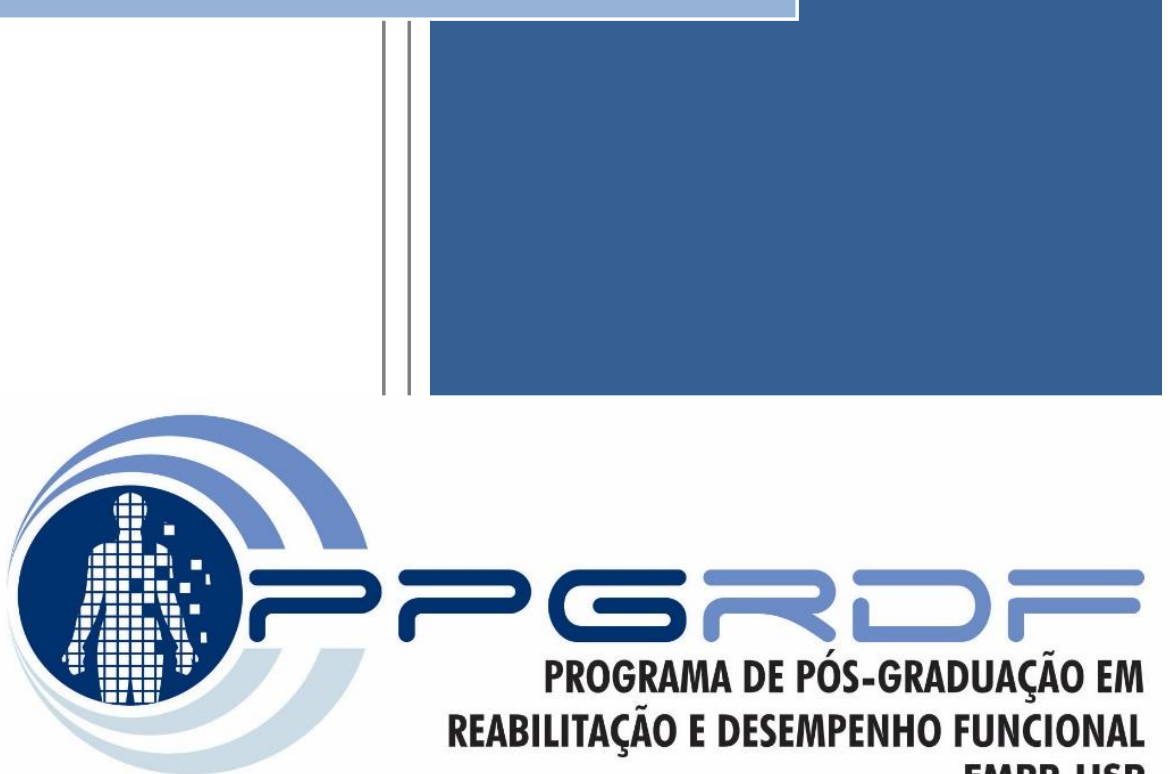
PROGRAMA DE PÓS-GRADUAÇÃO EM REABILITAÇÃO E DESEMPENHO FUNCIONAL

FMRP-USP

Antonio Carlos Ferraz de Andrade

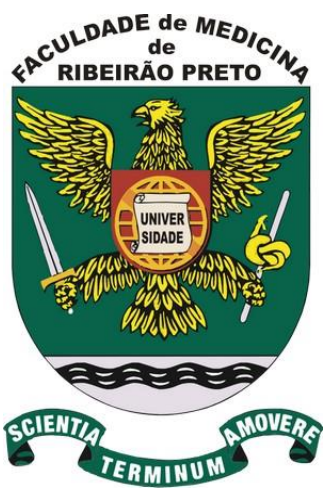

Dissertação 


\section{Análise biomecânica do pé de corredores recreacionais assintomáticos para lesões musculoesqueléticas e de corredores com dor femoropatelar}

Dissertação apresentada ao Programa de Pós-Graduação em Reabilitação e Desempenho Funcional da Faculdade de Medicina de Ribeirão Preto da Universidade de São Paulo, para obtenção do título de Mestre em Ciências.

Área de concentração: Fisioterapia

Orientador: Prof. Dr. Paulo Roberto Pereira Santiago

Ribeirão Preto - SP

2021

"Versão corrigida. A versão original encontra-se disponível tanto na Biblioteca da Unidade que aloja o Programa, quanto na Biblioteca Digital de Teses e Dissertações da USP (BDTD)") 
Autorizo a reprodução e divulgação total ou parcial deste trabalho, por qualquer meio convencional ou eletrônico, para fins de estudo e pesquisa, desde que citada a fonte.

de Andrade, Antonio Carlos Ferraz

Análise biomecânica do pé de corredores recreacionais assintomáticos para lesões musculoesqueléticas e de corredores com dor femoropatelar. Ribeirão Preto, 2021.

54 p. : il. ; $30 \mathrm{~cm}$

Dissertação de Mestrado apresentada à Faculdade de Medicina de Ribeirão Preto/USP. Programa de Pós-Graduação em Reabilitação e Desempenho Funcional. Área de concentração: Fisioterapia.

Orientador: Roberto Pereira Santiago, Paulo.

1. Músculos intrínsecos do pé. 2. Mobilidade do pé. 3. Corredores recreacionais. 4 . Cinemática. 


\section{DEDICATÓRIA}

Dedico este trabalho aos meus pais

(Antonio Carlos de Andrade e Neusa Maria Ferraz de Andrade),

minha irmã (Eliane Ferraz de Andrade),

minha esposa (Daniela Hernandes de Andrade)

e à minha filha (Helena Hernandes de Andrade),

pelo apoio e amor incondicional de vocês em todos os momentos da vida.

Amo vocês. 


\section{AGRADECIMENTOS}

Esta dissertação é o resultado de muita dedicação e esforço. Inúmeras são as pessoas e instituições que colaboraram. Tendo alcançado este objetivo, não poderia deixar de agradecer:

$\checkmark$ Primeiramente, meu orientador prof. Dr. Paulo Roberto Pereira Santiago, por ter me dado a oportunidade de seguir meu objetivo primário de pesquisa relativo à biomecânica do pé. Desde a nossa primeira conversa telefônica no início da jornada do mestrado você se mostrou solicito e disposto a auxiliar na empreitada. Com idéias inovadoras, conhecimento técnico-científico, acadêmico e incentivando o empreendedorismo de maneira inigualável, você me apoiou em momentos que nem eu mesmo acreditava ser capaz de executar tudo que fizemos.

$\checkmark$ À UNIVERSIDADE DE SÃO PAULO, à Escola de Educação Física e Esporte de Ribeirão Preto e ao Programa de Pós-Graduação em Reabilitação e Desempenho Funcional pela possibilidade de execução deste projeto.

$\checkmark$ A todos os professores do programa pelos quais tive o prazer de conviver durante as disciplinas e atividades realizadas durante o mestrado. Um agradecimento especial ao Prof. Dr. Renato de Moraes, pelos conhecimentos transmitidos e pela oportunidade de participar da disciplina ministrada pelo também não menos especial Prof. Dr. Richard Van Emmerik (University of Massachusetts).

$\checkmark$ Aos amigos que fiz durante este período na USP em Ribeirão Preto. Thiago Faria, meu agradecimento especial a você ("meu irmão") pela sua prestatividade e sempre disposição em auxiliar. Agradeço também ao técnico do LaBioCoM, Eduardo Bergonzoni (Du), por toda a ajuda dispensada em todos os momentos.

$\checkmark$ Aos colegas profissionais que encaminharam os participantes da pesquisa.

$\checkmark$ A todos os participantes que dispuseram de tempo para participar e colaborar com a ciência. 
$\checkmark$ Aos meus pais (Antonio e Neusa) e a minha querida irmã (Eliane), pelo apoio incondicional, incentivo e suporte.

$\checkmark$ A todos os familiares (meus e da parte da minha esposa) que direta e indiretamente torceram para que este meu desejo se tornasse realidade. Obrigado "tio Paulo" pela força, mentoria e incentivo de sempre.

$\checkmark$ Por último e mais importante, gostaria de agradecer imensamente a minha amada, companheira, parceira, linda e maravilhosa esposa (Daniela) pelo seu amor e suporte durante este período. Obrigado por existir na minha vida. Obrigado pela paciência e equilíbrio nos momentos da minha ausência. $\mathrm{O}$ seu apoio incondicional neste período foi fundamental. Obrigado também a você minha linda, amável, doce e carinhosa filha Helena. O seu sorriso contagiante alegrou o papai infinitas vezes e fez eu sempre me esforçar para ser um ser humano melhor em todos os aspectos da vida a cada dia. Papai te ama e sempre te amará filha. Amo vocês.

O presente trabalho foi realizado com apoio da Coordenação de Aperfeiçoamento de Pessoal de Nível Superior - Brasil (CAPES ) - Código de Financiamento 001 e Conselho Nacional de Desenvolvimento Científico e Tecnológico (CNPq) Universal \#432259/2018-0.

Antonio Carlos Ferraz de Andrade, Ribeirão Preto, abril 2021. 
Nome: De ANDRADE, Antonio Carlos Ferraz

Título: Análise biomecânica do pé de corredores recreacionais assintomáticos para lesões musculoesqueléticas e de corredores com dor femoropatelar

Documento apresentado à Faculdade de Medicina de Ribeirão Preto da Universidade de São Paulo, como parte dos requisitos exigidos para obtenção do título de Mestre em Ciências, na área de Reabilitação e Desempenho Funcional.

Aprovado em:

Prof. Dr.

Instituição:

Julgamento:

Assinatura:

Prof. Dr.

Instituição:

Julgamento:

Assinatura:

Prof. Dr.

Instituição:

Julgamento:

Assinatura:

Prof. Dr.

Instituição:

Julgamento:

Assinatura: 


\section{Resumo}

De Andrade, ACF. Análise biomecânica do pé de corredores recreacionais assintomáticos para lesões musculoesqueléticas e de corredores com dor femoropatelar. [dissertação]. São Paulo. Universidade de São Paulo. Faculdade de Medicina de Ribeirão Preto, 2021. 54p.

Objetivos: Avaliar a associação entre a força de flexão do hálux e a mobilidade geral do pé em corredores recreacionais sem disfunções musculoesqueléticas nos membros inferiores. Além disso, examinar se há diferenças cinemáticas nos movimentos da perna, calcâneo e o padrão de coordenação de movimento resultante da interação destes segmentos em corredores recreacionais sem comprometimento musculoesquelético nos membros inferiores e corredores com dor femoropatelar. Métodos: Corredores recreacionais sem comprometimentos musculoesqueléticos nos membros inferiores e corredores com dor femoropatelar foram incluídos. Inicialmente, apenas em corredores recreacionais sem disfunções musculosesqueléticas, foi mensurado com uma célula de carga a força de flexão plantar do hálux e pelo método descrito por McPoil et. al (2009) a mobilidade geral do pé. No segundo momento, foi realizada a avaliação cinemática de dezoito corredores recreacionais $(9$ sem disfunção musculoesquelética e 9 com dor femoropatelar). Foi realizada a comparação por meio do mapeamento estatístico paramétrico dos movimentos da perna no plano transverso, calcâneo no plano frontal e o vector coding do padrão de coordenação de movimento resultante da interação entre estes segmentos nos dois grupos. Resultados: Não houve associação significativa entre a força de flexão plantar do hálux e a mobilidade geral do pé. Não houve diferença estatisticamente significante entre os grupos para os movimentos da perna e retropé. Identificou-se diferença estatisticamente significativa entre os grupos para o padrão de coordenação de movimento. A coordenação anti-fásica com dominância distal do movimento de inversão do calcâneo na fase média do apoio foi maior no grupo de corredores sem disfunções musculoesqueléticas que no grupo com dor femoropatelar. A coordenação em fase com predominância distal da inversão sobre a rotação externa da perna foi maior no grupo com DFP durante a fase de propulsão, porém com tamanho de efeito pequeno. Conclusões: A força de flexão plantar do hálux não está associada à mobilidade do pé em corredores recreacionais sem lesões nas extremidades inferiores, mensurados através das ferramentas clínicas do estudo. Embora não tenha diferença entre os grupos para o movimento da perna e do retropé, o padrão de coordenação do movimento resultante da interação entre esses segmentos foi diferente entre os grupos. 
Palavras-chave: Biomecânica. Corredores Recreacionais. Músculos Intrínsecos do Pé. Mobilidade do pé. 


\begin{abstract}
De Andrade, ACF. Biomechanical analysis of the foot in recreational runners asymptomatic for musculoskeletal injuries and runners with patellofemoral pain. [dissertation]. São Paulo. University of São Paulo. Ribeirão Preto Medical School, 2021. 54p.

Objectives: To evaluate the association between hallux flexion strength and general foot mobility in recreational runners without musculoskeletal injuries in the lower limbs. Also, examine whether there are kinematic differences in shank, rearfoot and movement coordination pattern resulting from the interaction of these segments in recreational runners without musculoskeletal injuries in the lower limbs and those runners with patellofemoral pain.
\end{abstract} Methods: Recreational runners without musculoskeletal injuries in the lower limbs and with patellofemoral pain were included. Initially, only in recreational runners without musculoskeletal injuries, the hallux flexion strength and the general foot mobility were measured, respectively, with a load cell and by the method described by McPoil et. al (2009). In the second step, the kinematic evaluation of eighteen recreational runners ( 9 without musculoskeletal injuries and 9 with patellofemoral pain) was performed. The comparison was performed using statistical parametric mapping of the shank movements in the transverse plane, rearfoot in the frontal plane, and the vector coding of the movement coordination pattern resulting from the interaction between these segments in the two groups. Results: There was no significant association between the hallux flexion strength and the general foot mobility. There was no statistically significant difference between groups for the shank and rearfoot movements. A statistically significant difference was identified between the groups for the movement coordination pattern. Anti-phasi coordination with distal dominance of the rearfoot inversion movement in the middle phase of stance phase was greater in the group of runners without musculoskeletal disorders than in the group with patellofemoral pain. The in-phase coordination with distal predominance of the inversion over the external rotation of the shank was bigger in the group with patellofemoral pain during the propulsion phase, but with a small effect size. Conclusions: The hallux flexion strength is not associated with the foot mobility foot in recreational runners without injuries in the lower limbs measured using the clinical methods of the study. Although there is no difference between groups for shank and rearfoot movement, the movement coordination pattern resulting from the interaction between these segments was different between groups.

Key-words: Biomechanics. Recreational Runners. Intrinsic Foot Muscle. Foot Mobility. 


\section{Sumário}

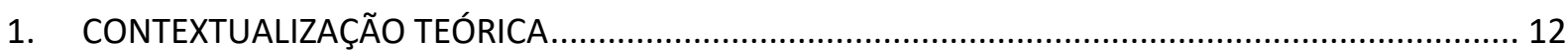

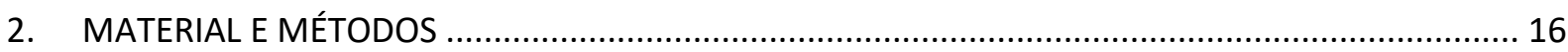

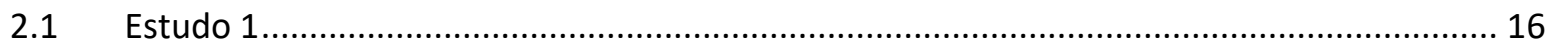

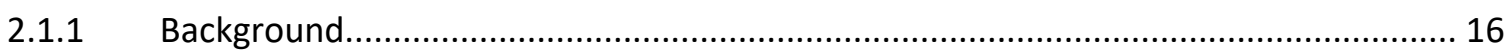

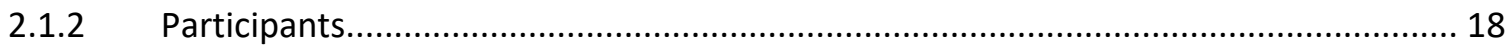

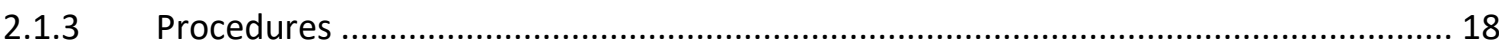

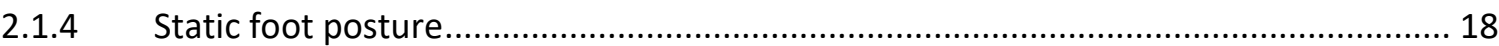

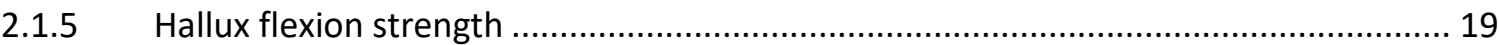

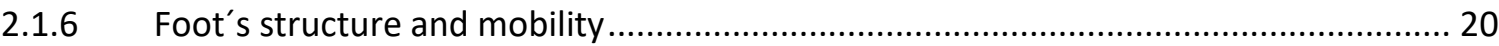

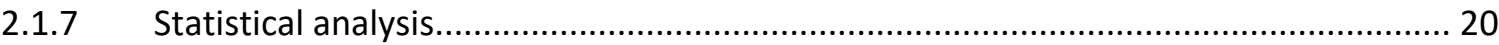

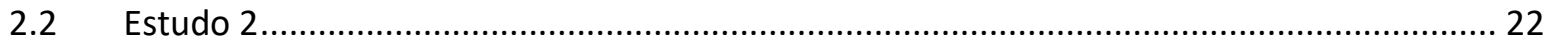

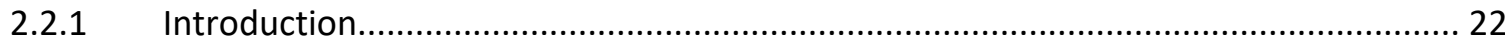

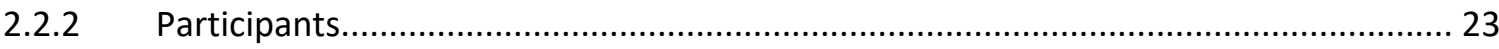

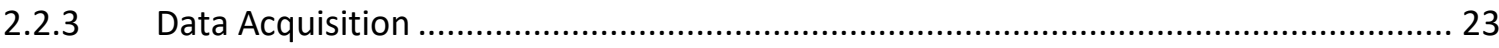

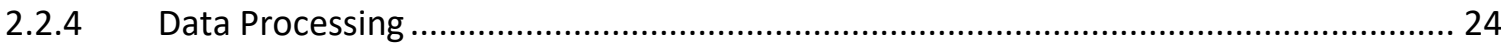

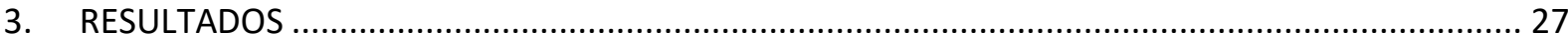

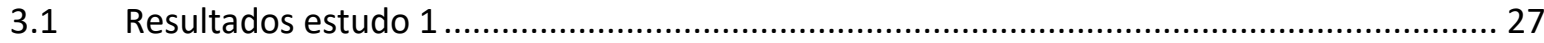

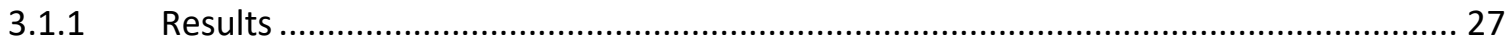

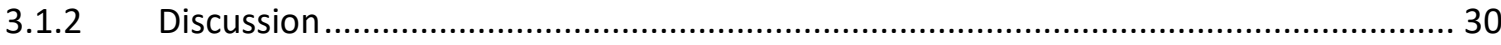

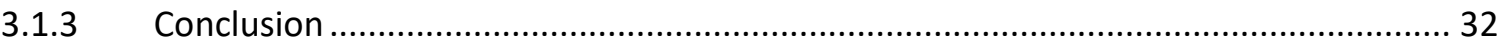

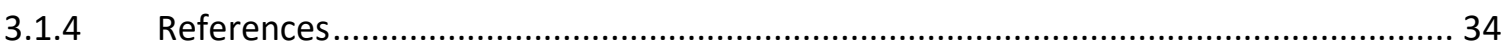

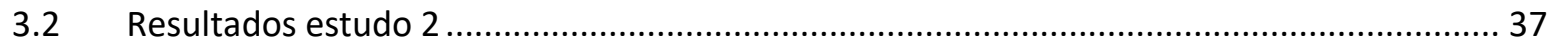

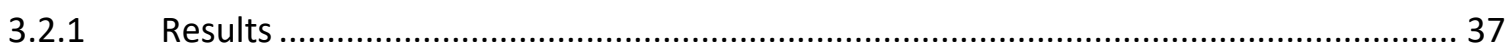

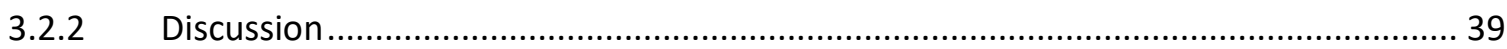

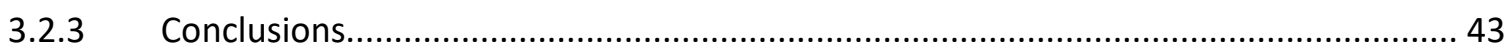

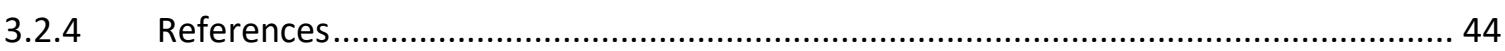

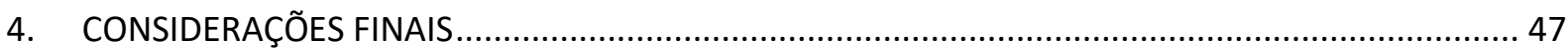

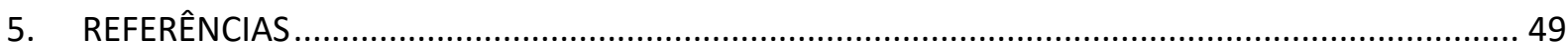

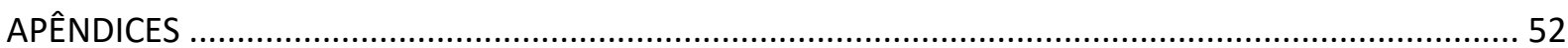




\section{CONTEXTUALIZAÇÃO TEÓRICA}

A corrida é praticada por aproximadamente 2.3 milhões de indivíduos no Brasil (MINISTÉRIO DO ESPORTE, 2015). A dor musculoesquelética relacionada à corrida pode acometer 22\% dos corredores (LOPES et al., 2011). O joelho (28\%), o tornozelo-pé (26\%), e a perna $(16 \%)$ são os principais locais anatômicos de ocorrência de lesões em corredores (FRANCIS et al., 2019).

A abordagem e o entendimento do tema corrida e das lesões que advém da sua prática talvez não tenham melhor introdução senão através do entendimento do pé. Ele é o único segmento da extremidade distal da cadeia cinética do membro inferior a tocar o solo durante a corrida (YAMAUCHI; KOYAMA, 2020). Neste contato, ele tem que conjugar flexibilidade e rigidez (MCKEON et al., 2015). A flexibilidade é importante para adaptar às alterações do solo e à carga a qual ele é submetido durante a fase de apoio. A rigidez, por sua vez, é necessária durante o toque do calcanhar e fase de impulso para transferir as forças dos flexores do tornozelo e deslocar o corpo anteriormente (WELTE et al., 2018). Essa rigidez é possível devido à presença do Arco Longitudinal Medial (ALM). Esta especialização estrutural permite ao pé funcionar como um sistema de alavanca rígido e compacto durante a fase tardia do apoio durante a corrida (MCKEON et al., 2015). A presença desta característica marcante do pé humano o distingue de seus ancestrais no processo evolutivo da espécie humana. Além disso, o ALM funciona como uma mola que se alonga e retrai, acumulando e liberando energia potencial elástica durante atividades como caminhar e correr (KELLY et al., 2014; LEARDINI et al., 2007). Há tempos, acreditava-se que esse alongamento e retração, conhecido como Foot Spring Mechanism, era realizado apenas de maneira passiva pela aponeurose ou fáscia plantar (HICKS, 1954). Não obstante, KELLY et al. (2014) demonstraram que os músculos intrínsecos do pé têm a capacidade de assistir ativamente o controle do ALM. A ação excêntrica dos músculos intrínsecos do pé controla o alongamento do arco longitudinal no início da fase de apoio, e a unidade miotendínea desses músculos acumula energia potencial elástica que será dissipada na fase tardia do apoio (KELLY et al., 2014). Essa musculatura também contribui ativamente para o aumento da rigidez da articulação metatarsofalangeana do hálux durante a fase tardia do apoio, auxiliando a propulsão durante a caminhada e corrida (FARRIS et al., 2019). O desempenho destas funções pelos músculos intrínsecos pode influenciar o padrão de coordenação do movimento do pé em atividades esportivas e/ou tarefas motoras. Há evidências demonstrando que a melhora da força de flexão do hálux pode melhorar o desempenho em 
testes físicos, a eficiência de corrida e até mesmo reduzir o risco de ocorrência de lesões (GOLDMANN; BRÜGGEMANN, 2012; SULOWSKA et al., 2019; TADDEI et al., 2020 a, b). Os humanos, quando correm, são os únicos que precisam controlar o equilíbrio durante o apoio unipodal e, por isso, exigem que o pé seja razoavelmente móvel, capaz de acomodar às superfícies irregulares, e com um controle ativo (MCKEON et al., 2015). Entretanto, esse controle pode estar prejudicado se alterações concernentes à mobilidade do pé estiverem presentes.

Estudos recentes sobre o arco transverso do pé demonstram que os tecidos intermetatarsais e a mobilidade metatarsal influenciam a rigidez do arco longitudinal medial do pé (VENKADESAN et al., 2020). Além disso, pesquisas demonstram que disfunções de mobilidade acarretam alterações estruturais e podem influenciar atividade motoras. Lin et al. (2001) relataram que o pé plano interfere em habilidades motoras e no desempenho físico de crianças. Além disso, estudos demonstram que há um subgrupo de indivíduos com dor femoropatelar que têm maior mobilidade do pé em comparação à controles saudáveis (MCPOIL et al., 2011). A mobilidade do pé aumentada nestes indivíduos com disfunção do joelho aumenta a pronação e desencadeia alterações cinemáticas na cadeia cinética dos membros inferiores (BARTON et al., 2010). Na prática clínica fisioterapêutica, no dia-dia de profissionais em educação física, treinadores esportivos, atletas e pessoas envolvidas com o manejo do movimento humano, inúmeras são as situações nas quais é necessário o entendimento da relação mecânica dicotômica entre força e mobilidade do pé. Dentre estas alterações nas quais pode haver alteração entre força e mobilidade do pé, a Dor Femoropatelar (DFP), que é queixa mais comum no joelho de corredores (FRANCIS et al., 2019; LOPES et al., 2011), pode ser um exemplo.

A DFP é uma condição crônica caracterizada por dor ao redor ou atrás da patela que piora durante pelo menos uma atividade com apoio de peso corporal sobre o joelho fletido (correr, agachar, subir/descer escadas, saltar/pular) (CROSSLEY et al., 2016). Embora a patogênese da DFP seja multifatorial (CROSSLEY et al., 2019), as alterações biomecânicas são amplamente estudas. Existem três categorias de fatores mecânicos que contribuem para a DFP: (i) fatores proximais (estabelece a relação entre quadril, pelve e tronco na DFP), (ii) fatores locais (correlaciona a estrutura e tecidos adjacentes ao joelho na patogênese da DFP), e (iii) fatores distais (são os fatores relacionados ao tornozelo e pé) (WITVROUW et al., 2014).

O subgrupo de indivíduos com DFP que têm maior mobilidade do pé geralmente apresenta uma pronação excessiva do mesmo (BARTON et al., 2010; MCPOIL et al., 2011). 
Essa configuração estrutural é comumente denominada "pé plano". Este tipo de pé apresenta o ALM com tendência a ser mais obtuso, abdução do antepé e eversão do retropé (BOLING et al., 2009). Essas características aumentam a rotação medial e adução do joelho durante atividades com apoio de peso corporal sobre o joelho fletido (POWERS, 2003; TIBERIO, 1987). Esse modelo de entendimento da DFP pressupõe que as alterações estruturais e de postura dos pés influenciam no acoplamento entre o complexo do tornozelo/pé e a cadeia cinética do membro inferior, aumentando o stress na articulação femoropatelar (POWERS et al., 2017). Estudos demonstram que durante a corrida de indivíduos com DFP há alterações no acoplamento entre o tornozelo-pé e os movimentos e cargas distribuídas no membro inferior. Noehren et al. (2012) não encontrou diferença no pico dos ângulos de eversão do retropé e abdução do antepé em corredoras com DFP e o grupo controle, porém verificou uma maior rotação medial do joelho no grupo com DFP. O estudo de Luz et al. (2018) demonstrou correlação entre o pico de eversão do retropé com o pico e amplitude de movimento de rotação medial, e o pico de adução do joelho. Além destes resultados, verificou também correlação do pico de eversão do retropé com o pico de adução do joelho em corredores com DFP. Não há um consenso sobre a relação entre a postura do retropé e a rotação medial do joelho em corredores recreacionais. Além disso, não há uma definição do padrão de coordenação de movimento resultante da interação entre estes segmentos em corredores recreacionais assintomáticos para lesões musculoesqueléticos nos membros inferiores e aqueles com dor femoropatelar.

A partir destas observações, fica evidente que a especialização estrutural do pé humano está atrelada ao equilíbrio entre os controladores ativos do ALM realizada pelos músculos intrínsecos do pé e a mobilidade geral dele. A conjugação destas funções mecânicas dicotômicas é um desafio para os humanos durante a corrida. Entretanto, apesar dessa relação eminente e sua importância, há uma lacuna no campo científico se existe associação entre capacidade de geração de força pelos músculos intrínsecos e a mobilidade geral do pé em corredores recreacionais. Além disso, não está completamente estabelecido o entendimento da relação do retropé e da perna. Não está completamente compreendido o padrão de coordenação do movimento resultante da interação entre estes segmentos em corredores recreacionais sem sintomas musculoesqueléticos e aqueles com dor femoropatelar.

Esta dissertação apresentará dois estudos desenvolvidos durante o período de mestrado. Embora não estejam diretamente relacionados, refletem algumas questões apresentadas na prática clínica do fisioterapeuta, profissionais em educação física, treinadores esportivos, 
praticantes de corrida e outros indivíduos envolvidos no manejo do movimento humano. No estudo 1, investigamos a associação entre a força de flexão plantar do hálux e a mobilidade geral do pé em corredores recreacionais assintomáticos para problemas musculoesqueléticos nos membros inferiores. No estudo 2, comparamos a cinemática do retropé, perna e o padrão de coordenação do movimento entre estes segmentos em corredores recreacionais assintomáticos para lesões musculoesqueléticas nos membros inferiores e corredores com dor femoropatelar.

O primeiro objetivo foi investigar em corredores recreacionais se há associação entre a força de flexão plantar do hálux e a mobilidade geral do pé em corredores recreacionais assintomáticos para lesões musculoesqueléticas nos membros inferiores. O segundo objetivo foi examinar se há diferença cinemática no movimento da perna, retropé e o padrão de coordenação do movimento entre estes segmentos em corredores recreacionais assintomáticos para lesões musculoesqueléticas nos membros inferiores e corredores com dor femoropatelar. A primeira hipótese foi da existência de uma associação entre força de flexão plantar do hálux e a mobilidade geral do pé devido à estreita relação entre ambas. A outra hipótese foi de haver diferença cinemática entre os movimentos do retropé e perna, além de diferença entre o padrão de coordenação do movimento entre estes segmentos. 


\section{MATERIAL E MÉTODOS}

\subsection{Estudo 1}

\subsubsection{Background}

Running-related musculoskeletal pain can reach 22\% of runners (Lopes et al., 2011). The ankle-foot represents $26 \%$ of all injuries present in runners (Francis et al., 2019). As the first component of the kinetic chain to touch the ground during running, the human foot has to be stiff enough during foot-strike and push-off, and mobile-compliant during the stance phase (McKeon et al., 2015).

The arrangement between bones, ligaments, and joint capsules creates the arch of the foot (McKeon et al., 2015), and these structures configure the foot's morphology as a half dome. The longitudinal medial and transverse arch are the most studied. A recent investigation of the foot's transverse arch in vitro demonstrated that intermetatarsal tissues and metatarsal mobility influence medial longitudinal stiffness of the foot (Venkadesan et al., 2020). The medial longitudinal arch plays an important role in locomotion as well, and it supports body weight in standing posture and dynamic movements (Morita et al., 2015). Furthermore, it acts as a spring or a rubber ball absorbing and storing elastic strain energy from the body in the first half of the stance phase of running and returning it in the second half, making running more energy efficient (Ker et al., 1987). The structural and morphological alterations in the longitudinal arch can lead to greater pronation of the foot and can lead to dysfunctions. Lin et al. (2001) related that flatfoot leads to poor motor skills and physical performance in children. Individuals with patellofemoral pain syndrome have more foot mobility compared to those match controls (McPoil et al., 2011). This augmented mobility leads to a more pronated foot and causes kinematic alterations in the lower limb kinetic chain (Barton et al., 2010).

Although the theory of foot postural alterations predominated for a long time, it is known that some athletes and people with the pronated foot are asymptomatic and free from injuries in lower limbs. Recent studies have demonstrated that people with pronated feet and with injuries in lower limbs have a smaller cross-sectional area of intrinsic foot muscles compared with people with the pronated foot but free from injuries in lower limbs (Zhang et al., 2019). Furthermore, some studies also have demonstrated that individuals with 
patellofemoral pain syndrome with greater midfoot mobility treated with foot orthoses and hip exercises demonstrated similar outcomes (Matthews et al., 2020). Based on these observations, it remains the question if these structural and postural alterations as foot pronation could be compensated with a more efficient function of the foot's intrinsic muscle strength, and how mobility and strength are associated in the foot.

The plantar intrinsic muscles are functionally linked with the transverse and longitudinal medial arch (Soysa et al., 2012), and play an important role in foot functions. Foot's intrinsic muscles can stiffen the longitudinal arch during the push-off phase of running (Farris et al., 2019), and control the foot posture (Kelly et al., 2014). They could guarantee an efficient transference of power generated by ankle flexor as soleus and gastrocnemius muscle. The weakness of the plantar intrinsic foot muscle is observed in individuals with plantar fasciopathy (Allen \& Gross, 2003). Intrinsic foot muscles and foot mobility may be influenced by physical activity levels and use of footwear. Kenyan adolescents accustomed to barefoot running and engaged in more vigorous physical activity have stronger intrinsic foot muscle and greater foot mobility than match controls accustomed shod running. The prevalence of injuries in habitually barefoot was $8 \%$ versus $61 \%$ among accustomed shod (Aibast et al., 2017). Strengthening exercise programs of intrinsic foot muscle can improve performance in physical tests (Goldmann et al., 2013; Sulowska et al., 2019). From these observations, there seems to be a correlation between intrinsic foot muscle, foot mobility and running performance.

The questions mentioned above show the possibility of an association between the foot's mobility and strength of the intrinsic muscles that control the arch of the foot. In clinical practice, professionals deal with situations that require approaches whose objectives are to increase mobility, increase intrinsic foot muscle strength, or the use of foot orthoses. This dichotomous relationship may cause difficulties for sports coaches, physiotherapists, runners, and people involved in running activities to achieve the best strategies to prevent and treat injuries in this segment. In recreational runners free from injuries in the lower limb this relationship it is not fully understood. The objective of this cross-sectional study was to investigate if there is an association between the intrinsic foot muscle's strength and foot mobility in recreational runners free from injuries. 


\subsubsection{Participants}

This cross-sectional and correlational study investigated 24 recreational runners selected via social media announcements. The principal investigator performed previous telephone screenings of potentially eligible participants. Study inclusion criteria involved age between 18-45 years, run at least 15 kilometers/week, free from lower extremity musculoskeletal disorders. Non-inclusion criteria involved ligament laxity, meniscal pathology, patellar tendonitis, knee pain from acute trauma, patellar dislocation, lower limb surgeries, degenerative diseases, and pregnancy. The Ethics Committee approved the study (CAAE: 04404918.7.0000.5659) that was performed according to the Declaration of Helsinki. All participants provided written informed consent to participation.

\subsubsection{Procedures}

Twenty-four participants (whose characteristics are described in table 1) were included in the study. The Dominant side was determined by asking for participants: "Which foot would you use to kick a ball as far as possible?". It was required to be barefoot and with shorts. Both legs were assessed in random order. Part of the data was collected during the Covid-19 pandemic period, and all biosafety criteria were strictly followed.

\subsubsection{Static foot posture}

Foot Posture Index (FPI-6) is a 6-item foot posture assessment and classification tool of foot posture. It is performed with the participant in a relaxed stance posture with weight-bearing distributed equally $50 \%$ between both feet. It is a 6-items assessment tool with scores ranging from -2 to +2 , and with a sum between -12 (highly supinated) and +12 (highly pronated) (Redmond et al., 2006). We classified feet as supinated (-12 to -1$)$, normal (0 to +5$)$, and pronated $(+6$ to +12$)$. 


\subsubsection{Hallux flexion strength}

The force of the muscles that control the medial longitudinal arch of the foot was measured with a load cell linked with an Arduino (an open-source electronic prototyping platform) for the signal acquisition of force in Kilograms. We used a custom-made foot's strength measurement wooden platform with a setup to stabilize the ankle-foot complex (Figure 1). The device was similar and based on that used by (Quek et al., 2015) who verified excellent intra-rater reliability $(\mathrm{ICC}=0.982, \mathrm{CI}=0.96-0.99)$.

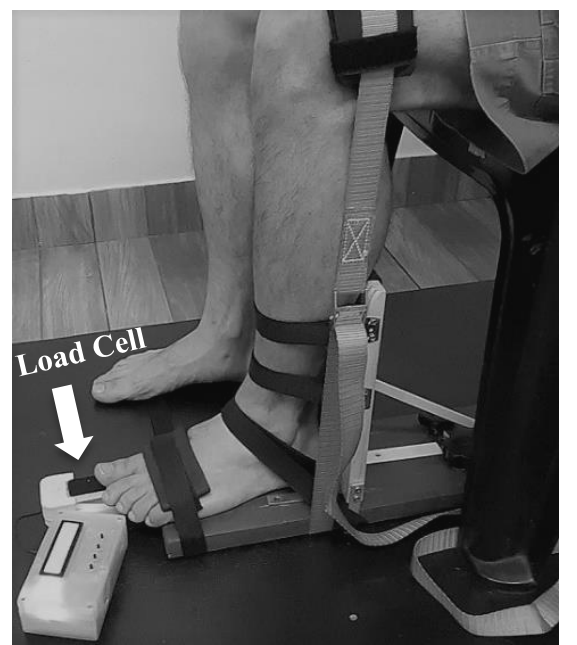

Figure 1 Measurement of hallux flexion strength in a wooden platform with a setup to stabilize the ankle-foot complex.

Participants stood seated in a chair with an angle of $90^{\circ}$ between ankle-foot/shank, shank/thigh, thigh/trunk, with the arms remained crossed in front of the chest. The forefoot, ankle, and distal shank were stabilized with Velcro straps to avoid joint movements of them. Another inelastic strap was used to stabilize the knee. A load cell was aligned to the plantar surface of the hallux. It was instructed to participants press the hallux towards the ground, trying to do a doming of the foot. Participants were instructed to avoid flexion of the interphalangeal joint of the hallux, hallux adduction, raise the heel, activate hamstring, push the chair back. They trained until familiarization and correct execution of the movement. A maximal isometric force was collected 5 seconds three times, with 30 seconds resting between each trial. The maximum hallux flexor force capacity was normalized by body weight times body height, compounding the normalized foot strength. (Endo et al., 2002). 


\subsubsection{Foot's structure and mobility}

We measured foot structure and mobility with a method previously described and validated by (McPoil et al., 2009). The participant stood on a custom-made wooden platform with the heels 15 centimeters apart and weight-bearing equally distributed in both feet. The distance of the most posterior aspect of the calcaneus to the most distal point of the foot (first or the second toe, depending on which was longer) represented the foot length. This foot length was normalized by the participant's height $(* 100)$ and resulted in the normalized foot length. We made a marker with a pen at the dorsum of the foot at $50 \%$ of the foot length. At this point of midfoot, we measured the foot arch height (FAH) and midfoot width (MFW) in weightbearing (WB) with a combination square and with a modified caliper, respectively. The participant was then seated on an examination plinth with the legs hanging freely on edge. A plastic portable platform with 80-grit sandpaper touched the plantar surface of the foot and was used to support the combined square for the measure of the foot arch height. The same measures made in weight-bearing were collected in non-weight bearing (NWB). Foot mobility was determined by: (i) foot arch height in WB subtracted from foot arch height in NWB [DiffFAH]; (ii) midfoot width in NWB subtracted from midfoot width in WB [DiffMFW]. General foot mobility was represented by the composition of the vertical and medio-lateral mobility and was obtained as: $\sqrt{\left((D i f f F A H)^{2}+(D i f f M F W)^{2}\right)}$.

\subsubsection{Statistical analysis}

Descriptive statistics were performed. Shapiro-Wilk test determined the normality of the data. Histograms and boxplots were plots for exploratory analysis of the data and identification of outliers.

The Foot Posture Index (FPI-6) is a tool with ordinal items that cannot be analyzed with statistical parametric tests. We used Rasch analysis to transform ordinal scores obtained by summing scores from each item of FPI-6 into interval measures with "logit values" (Keenan et al., 2007). Parametric tests analyzed these unidimensional measures.

Data from dominant and non-dominant limbs were included in different data sets for an independent analysis. Paired Sample T-tests determined differences between dominant and non-dominant sides. 
Pearson's and Spearman's correlation coefficients determined the relationship between Normalized Strength and variables as general foot mobility, normalized foot length, foot height, and foot width (in weight-bearing posture), and the difference in foot arch height and midfoot width in weight and non-weight-bearing. Significance was set at $p<0.05$ for all statistical methods, and all procedures were performed with JASP software (Version 0.14). 


\subsection{Estudo 2}

\subsubsection{Introduction}

The musculoskeletal pain related to running can affect $22 \%$ of runners (Lopes et al., 2011). The knee (28\%), the ankle-foot (26\%), and the shank $(16 \%)$ are the main anatomical sites for the occurrence of injuries in runners (Francis et al., 2019).

Patellofemoral pain (PFP) is the most common complaint in the runner's knee (Francis et al., 2019; Lopes et al., 2011). It is a chronic condition characterized by pain around or behind the patella, which worsens during at least one activity with weight-bearing on the flexed knee (running, squatting, up/downstairs, jumping) (Crossley et al., 2016). Although the pathogenesis of PFP is multifactorial (Crossley et al., 2019), biomechanical changes are widely studied. There are three categories of mechanical factors that contribute to PFP: (i) proximal factors (establishes the relationship between hip, pelvis, and trunk in PFP), (ii) local factors (correlates the structure and tissues adjacent to the knee in the pathogenesis of PFP), and (iii) distal factors (these are factors related to the ankle and foot) (Witvrouw et al., 2014).

There is a subgroup of individuals with PFP that usually have increased foot mobility with excessive foot pronation (Barton et al., 2010; McPoil et al., 2011). Due to a link between the rearfoot's posture with the shank, increased rearfoot eversion can cause knee internal rotation, and adduction during weight-bearing activities on the flexed knee (Powers, 2003; Tiberio, 1987). These distal factors to the knee may influence the coupling between the ankle/foot complex, and increase stress on the patellofemoral joint (Powers et al., 2017). However, despite this model of the connection between these segments, Neal et al. (2016) showed limited evidence of the difference of the kinematic discrete measures of rearfoot kinematic variables between runners with PFP, and those health controls. On the other hand, some studies reveal that runners with PFP have more shank internal rotation than health control runners (Noehren et al., 2012). Although there is a current model of the connection between these two kinematic variables influencing the biomechanics of the patellofemoral joint, there is a scientific gap of the interaction between them in runners with patellofemoral pain.

Vector Coding is a method that analyzes the interaction between segments resulting in movement coordination patterns. Movement coordination pattern is a process in which the multiple degrees of freedom of the segments are in proper relation (Turvey, 1990). The coupling means that the motion of one segment can influence the motion of another segment (Hamill, 
Palmer and Van Emmerik, 2012). Some authors demonstrate with this method that there were significant differences between health runners and runners with PFP (Rodrigues et al., 2015). They showed that between $34 \%-38 \%$ of the stance phase of running the PFP group had more shank internal rotation than eversion.

Therefore, the aims of this study were to examine if there were differences in the movement of the shank in the transverse plane $(\mathrm{Z})$, rearfoot in the frontal plane $(\mathrm{Y})$, and the movement coordination pattern between these segments among recreational runners free from injuries in lower extremities, and those with patellofemoral pain syndrome.

\subsubsection{Participants}

A total of eighteen recreational runners participated in the study [control group $(\mathrm{CG})=$ 9; patellofemoral pain group $(\mathrm{PFPG})=9)]$. They were recruited via advertisements in social media, within the running groups, or contacted directly via phone calls by the investigators of the laboratory staff. A single experienced assessor with 20 years of experience in clinical practice performed the evaluation. The inclusion criteria involved age between 18-45 years, and run at least 15 kilometers/week for both groups. The control group was free from lower extremity musculoskeletal disorders. The patellofemoral pain group had to: present patellofemoral pain for at least 3 months; experience minimum pain levels of 3/10 around or behind the patella, aggravated by activities that load the patellofemoral joint during weightbearing on a flexed knee (running, squatting, stair ambulation, and hopping/jumping) (Crossley et al., 2016). Non-inclusion criteria was: ligament laxity; meniscal pathology; patellar tendonitis or knee pain from acute trauma; previous history of patellar subluxation or surgery on the lower limb; presence of rheumatoid, neurological or degenerative diseases; pregnancy; and lower limb length discrepancy greater than $1.0 \mathrm{~cm}$. The Ethics Committee of the University of São Paulo approved the study (CAAE: 04404918.7.0000.5659) that was performed according to the Declaration of Helsinki. All participants provided written informed consent to participation. Part of the data was collected during the Covid-19 pandemic period, and all biosafety criteria were strictly followed.

\subsubsection{Data Acquisition}

The evaluation session of the participants lasted approximately 1 hour. They were barefoot and in shorts. The data for both lower limbs were collected. In the CG, the dominant 
side was included in the comparative analysis. Dominance was determined by asking for participants: "Which foot would you use to kick a ball as far as possible?" (Ford, Myer and Hewett, 2003). In the PFPG, the most symptomatic lower limb was included in the analysis. In the cases in which both sides were equally symptomatic the dominant side was analyzed.

Reflective markers (9.5 $\mathrm{mm}$ in diameter) were placed on foot and shank (right and left) according to the Rizzoli Foot Model (Leardini et al., 2007). Markers were also affixed to the trunk on posterior superior iliac spines (right and left) to calculate stance phases, great trochanter (right and left), and anterior superior iliac spine (right and left). The local reference frames were defined on the shank, rearfoot, midfoot, and forefoot segments.

A static trial was carried out for 5 seconds. The participant stood upright on the treadmill, with feet apart at a distance equivalent to the width of the shoulders. Shoulder it was in $90^{\circ}$ abduction, with the palms of the hands facing down. These data were used as reference values of joint angles neutral position. After the static trial, the participant walked barefoot for 5 minutes at a speed of $1.00 \mathrm{~m} \cdot \mathrm{s}^{-1}$, as naturally as possible to familiarization with the treadmill. The speed's treadmill was increased by $0.14 \mathrm{~m} . \mathrm{s}^{-1}$ every 30 seconds until the instant when the participant could no longer refrain from running and did not be able to just walk. This speed was defined as the maximum walking or slow running speed (Pohl, Messenger and Buckley, 2007). When they were familiarized with this speed on the treadmill, a period of 2 minutes was collected. Static and running data were measured using a three-dimensional motion analysis system (Optitrack, Corvalis, USA), with nineteen cameras tracking marker trajectories at a sampling rate of $250 \mathrm{~Hz}$.

\subsubsection{Data Processing}

The raw kinematic data from the static trial and the marker's trajectory of the running trial were processed in Motive (Optitrack, Corvalis, USA, v.1.9.0) and Visual3D (C-Motion, USA, v6.0). The data was filtered using a 4th order Butterworth filter with a lower cut-off at the frequency of $8 \mathrm{~Hz}$ (Chang, Van Emmerik and Hamill, 2008; Cunningham et al., 2014). For each coordinate system, rotation around the anteroposterior axis (Y) was defined as inversion/eversion (+/-), and around the longitudinal axis (Z) as internal/external rotation (+/-) (Arnold et al., 2017). The distal segment joint angle was expressed relative to the adjacent proximal segment.

The entire data collected in 2 minutes were exported in a c $3 \mathrm{~d}$ file, and a python code based on Zeni's algorithm (Zeni, Richards and Higginson, 2008) determined all stance phases 
(heel strike and toe-off). It was identified for the right and left sides a mean of 118 stance phase in the CG, and 119 stance phase in the PFPG. One participant had 99 stance phase in the CG. Therefore, we included in the comparative analysis the mean joint angles of one stance phase (101 points) resulted from the mean of 99 stance phase depending on the side of interest, for each participant in both groups. The stance phase duration was divided into 3 periods: (i) early stance (1-33\% of the stance phase); (ii) midstance (34-66\% of the stance phase); (iii) propulsion (67-100\% of the stance phase) (Chang, Van Emmerik and Hamill, 2008; Cunningham et al., 2014).

The coordination pattern between shank in the transverse plane $(\mathrm{Z})$ and rearfoot in the frontal plane (Y) were assessed using the Vector Coding (Van Emmerik, Miller and Hamill, 2013). Joint kinematics isolated can not produce adequate information about the inter-joint coordination pattern that results in angular positions (Chang, Van Emmerik and Hamill, 2008). The relative movement between two joints or body segments can be represented by the angular time-series through "angle-angle diagrams". The horizontal axis (" $x$ " axis) of this diagram represents the angular movement of the proximal segment (shank in Z-axis), and the vertical axis ("y" axis) represents the angular movement of the distal segment (rearfoot in Y-axis). The movement and the coordination pattern between segments it was quantified by the coupling angle. It is an angle subtended from a vector adjoining from two successive points in the timeseries and the right horizontal (Van Emmerik, Miller and Hamill, 2013) (Figure 1-b). Mean coupling angles were categorized into one of eight coordination patterns (Needham, Naemi and Chockalingam, 2015) (Figure 1- a). Given the relationship between rearfoot and shank, we defined movement coordination pattern as in phase when shank internal rotation with rearfoot eversion, or shank external rotation with rearfoot inversion. The anti-phase coordination was defined as shank internal rotation with rearfoot inversion, or shank external rotation with rearfoot eversion (Chang, Van Emmerik and Hamill, 2008; Tiberio, 1987). Proximal and distal dominance was defined as a predominant angular movement of the shank and rearfoot, respectively. 


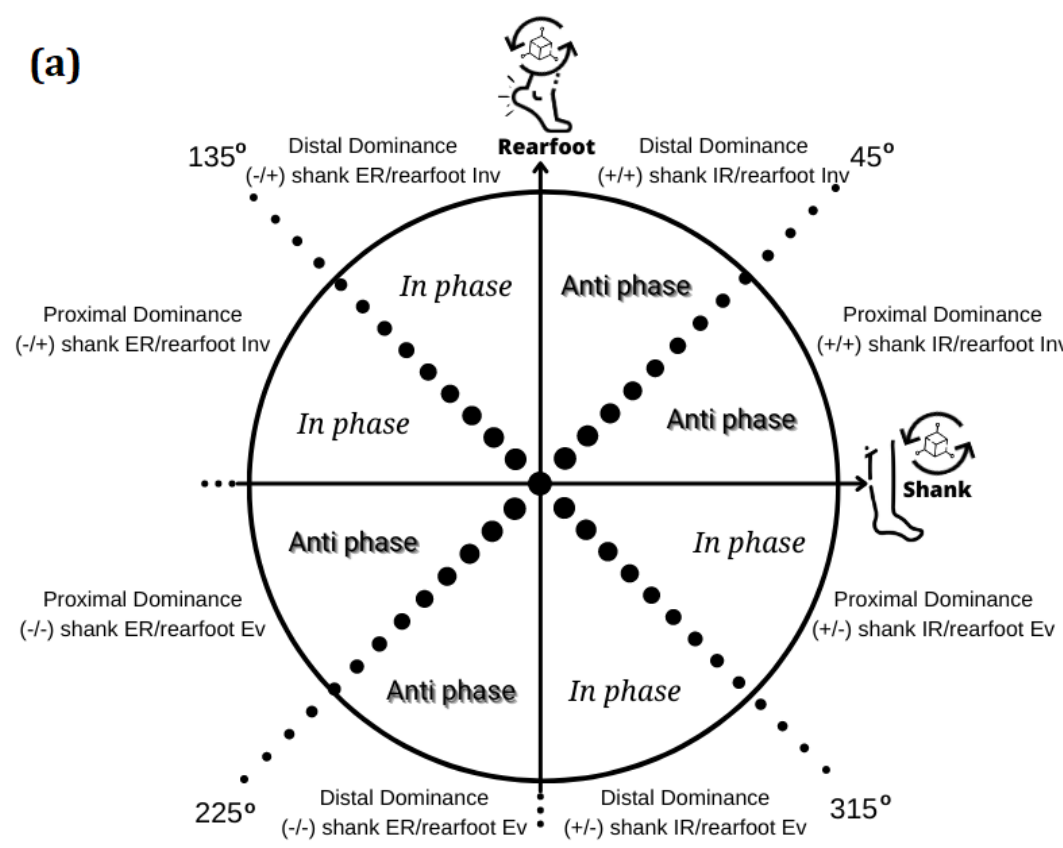

\section{(b)}

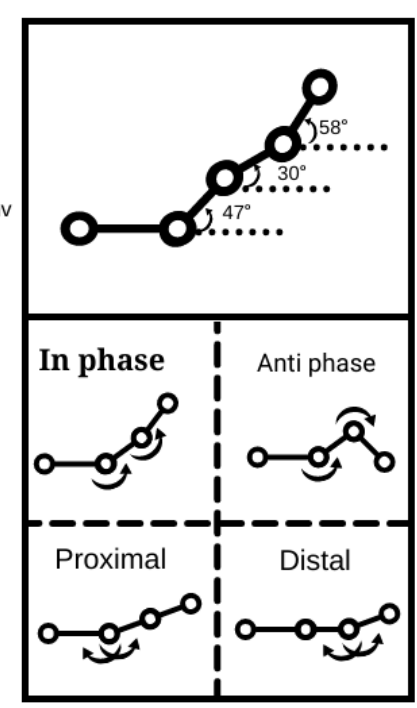

Figure 01. a. Esquematic representation of the angle-angle diagram of the shank (horizontal axis) and rearfoot (vertical axis). Classification of the coordenation pattern. The Coupling Angle it is included into 8 bins, that cathegorized 4 coordination pattern (In phase with proximal dominance; In phase with distal dominance; Anti phase with proximal dominance and Anti phase with distal dominance). IR $=$ Internal Rotation; ER $=$ External Rotation; Inv = Inversiton and Ev = Eversion. b. Graphical representation of two sucessive time-points between shank and rearfoot.

The comparing between groups for the movement of the shank in $\mathrm{Z}$ plane, rearfoot in $\mathrm{Y}$ plane, and the vector coding of both groups was executed with a two-sample t-test with Statistical Parametric Mapping. The statistical level of significance was established at 0.05. This analysis it was performed with a python script developed by Pataky (2020). The comparing of relative frequency between groups for each of the coordination patterns it was executed with the "prop.test" function in RStudio (RStudio, 2020), with the package pwr (v1.3-0). This function can test if the proportion of occurrence of the coordination patterns were the same in the groups. Significance level was set at $\mathrm{p}<0.05$. 


\section{RESULTADOS}

\subsection{Resultados estudo 1}

\subsubsection{Results}

The participants characteristics are presented in Table 1. The distribution of foot's posture according to FPI-6 for both sides were: supinated $(n=2$ dominant and $n=3$ nondominant), normal ( $\mathrm{n}=20$ dominant and $\mathrm{n}=19$ non-dominant) and pronated $(\mathrm{n}=2$ dominant and $\mathrm{n}=2$ non-dominant).

Table 1 Participant's characteristics

\begin{tabular}{lc}
\hline Variable & Participants $(\mathbf{n}=\mathbf{2 4})$ \\
\hline Age (years mean (SD)) & $33.58(7.13)$ \\
Sex (female n (\%)) & $6(25 \%)$ \\
Height (m mean (SD)) & $1.71(0.07)$ \\
Mass (kg mean (SD)) & $70.30(10.28)$ \\
BMI (kg/m ${ }^{2}$ mean (SD)) & $70(60)$ \\
Time Training (months mean (SD)) & $19(79.17)$ \\
& \\
\hline
\end{tabular}

SD standard deviation; m meter; kg kilograms; BMI body mass index

There were no significant differences between dominant and non-dominant sides (Table 2), for Foot Posture Index (95\% CI: -0.098 to 0.418; p = 0.213), normalized foot strength (95\% CI: -0.142 to $0.673 ; p=0.201$ ), Foot Arch Height (WB) (95\% CI: -0.091 to 0.731, p = 0.127), Midfoot Width (WB) (95\% CI: -0.129 to 0.687, p = 0.180), Foot Arch Height (NWB) (95\% CI: -0.218 to $0.589, \mathrm{p}=0.368$ ), DiffFAH (95\% CI: -0.519 to $0.284, \mathrm{p}=0.567$ ), DiffMFW (95\% CI: -0.542 to $0.262, p=0.494)$, general foot mobility (95\% CI: -0.757 to $0.068, p=0.101$ ). 
There was statistical difference between normalized foot length $(95 \%$ CI: -0.129 to $-0.008, p=$ 0.029 , effect size $=-0.475)$ and midfoot width $(\mathrm{NWB})(95 \% \mathrm{CI}: 0.029$ to $0.212, \mathrm{p}=0.012$, effect size $=0.558$ ).

Table 2 Means and standard deviations of each of the variables, $p$ values, and Confidence Interval comparing dominant and non-dominant sides.

\begin{tabular}{lcccc}
\hline & Dominant & Non-Dominant & & 95\% CI \\
Variable & Mean (SD) & Mean (SD) & $p$ value & {$[$ lower, upper $]$} \\
\hline Foot Posture Index (FPI-6) & $1.16(1.45)$ & $1.00(1.42)$ & 0.213 & {$[-0.098,0.418]$} \\
Normalized Foot Length & $14.99(0.47)$ & $15.06(0.44)$ & 0.029 & {$[-0.129,-0.008]$} \\
Normalized Foot Strength & $12.63(3.73)$ & $12.38(3.90)$ & 0.201 & {$[-0.147,0.658]$} \\
Foot Arch Height (cm) - WB & $6.72(0.47)$ & $6.64(0.55)$ & 0.127 & {$[-0.024,0.183]$} \\
Midfoot Width (cm) - WB & $8.57(0.62)$ & $8.50(0.61)$ & 0.180 & {$[-0.035,0.177]$} \\
Foot Arch Height (cm) - NWB & $7.82(0.42)$ & $7.77(0.54)$ & 0.368 & {$[-0.063,0.163]$} \\
Midfoot Width (cm) - NWB & $7.28(0.52)$ & $7.16(0.53)$ & 0.012 & {$[0.029,0.212]$} \\
DiffFAH (cm) & $1.10(0.23)$ & $1.13(0.25)$ & 0.567 & {$[-0.133,0.075]$} \\
DiffMFW (cm) & $1.29(0.37)$ & $1.34(0.34)$ & 0.494 & {$[-0.199,0.099]$} \\
General Foot Mobility (cm) & $1.73(0.29)$ & $1.79(0.26)$ & 0.101 & {$[-0.135,0.013]$} \\
\hline & & & & \\
\hline
\end{tabular}

Notes: SD Standard Deviation; cm (centimeters); CI (Confidence Interval); FPI (Foot Posture Index); WB (Weight Bearing); NWB (Non-Weight Bearing); DiffFAH (Difference Foot Arch Height); DiffMFW (Difference Midfoot Width).

Foot height, width (dominant), and foot height (non-dominant) revealed outliers in a previous exploratory analysis. We used Spearman's Correlation Coefficient to analyze these variables and Pearson for all others without outliers. Correlation between normalized strength 
and other variables are presented in Table 3. There was a poor and no significant correlation between normalized strength and foot's general mobility, normalized foot length, foot's height and width (in weight-bearing), and difference in foot arch height and midfoot width. 
Table 3 Correlations between general foot mobility, normalized foot length, foot height, foot width, DiffFAH, DiffMFW, and normalized foot strength for dominant and non-dominant sides.

\begin{tabular}{|c|c|c|c|c|}
\hline \multirow[b]{2}{*}{ Variable } & \multicolumn{2}{|c|}{$\begin{array}{c}\text { Normalized Strength } \\
\text { (Dominant) }\end{array}$} & \multicolumn{2}{|c|}{$\begin{array}{c}\text { Normalized Strength } \\
\text { (Non-Dominant) }\end{array}$} \\
\hline & value & $\begin{array}{l}p \text { value } \\
95 \% C I\end{array}$ & value & $\begin{array}{l}p \text { value } \\
95 \% C I\end{array}$ \\
\hline General Foot Mobility (cm) & $0.063(r)$ & $\begin{array}{c}0.771 \\
{[-0.349,0.455]}\end{array}$ & $0.119(r)$ & $\begin{array}{c}0.579 \\
{[-0.299,0.499]}\end{array}$ \\
\hline Normalized Foot Length & $-0.076(r)$ & $\begin{array}{c}0.723 \\
{[-0.338,0.465]}\end{array}$ & $0.117(r)$ & $\begin{array}{c}0.587 \\
{[-0.301,0.497]}\end{array}$ \\
\hline Foot Arch Height (WB) (cm) & $-0.224(r h o)$ & $\begin{array}{c}0.292 \\
{[-0.575,0.197]}\end{array}$ & $-0.095(r h o)$ & $\begin{array}{c}0.658 \\
{[-0.480,0.320]}\end{array}$ \\
\hline Midfoot Width (WB) (cm) & 0.134 (rho) & $\begin{array}{c}0.532 \\
{[-0.285,0.510]}\end{array}$ & $0.146($ rho $)$ & $\begin{array}{c}0.495 \\
{[-0.273,0.519]}\end{array}$ \\
\hline DiffFAH $(\mathrm{cm})$ & 0.158 (rho) & $\begin{array}{c}0.461 \\
{[-0.262,0.528]}\end{array}$ & 0.145 (rho) & $\begin{array}{c}0.500 \\
{[-0.275,0.518]}\end{array}$ \\
\hline DiffMFW (cm) & 0.124 (rho) & $\begin{array}{c}0.565 \\
{[-0.294,0.502]}\end{array}$ & $-0.001($ rho $)$ & $\begin{array}{c}0.995 \\
{[-0.404,0.402]}\end{array}$ \\
\hline
\end{tabular}

Notes: $C I$ Confidence Interval; $r$ Pearson's Correlation Coefficient; rho Spearman's Correlation Coefficient; DiffFAH (Difference Foot Arch Height); DiffMFW (Difference Midfoot Width).

\subsubsection{Discussion}

An objective measure of the hallux flexion strength it is necessary to establish parameters of evolution in programs of rehabilitation and performance. The measurement can be classified into: i) indirect methods (do not directly measure strength but provide information about the structure and activity of these muscles), and ii) direct methods that measure the units of force (Soysa et al., 2012). Quek et al. (2015) measured hallux flexor strength with a Nintendo Wii Balance Board in individuals seated and results demonstrated excellent intra-rater reliability $(\mathrm{ICC}=0.982)$. We used a similar measurement but with a load cell. Furthermore, we decided to use a custom-made foot's strength measurement wooden platform with a special setup to stabilize the ankle-foot complex. This set avoids raising the heel by the interference of soleus and hamstrings activities by knee flexion. We used extra inelastic straps to stabilize the forefoot, midfoot, and distal shank. This new set up was like that used by Allen \& Gross (2003) to evaluate toe flexors strength in individuals with plantar fasciitis. This author encountered 
values of intraclass coefficient of correlation for intra-rater reliability equal to 0.99 . We believe this method of stabilization is important to avoid underestimating the values of strength development capacity. The mean values of our non-normalized results of strength are like those results encountered by Allen \& Gross, although it was a population with different characteristics.

Although it is difficult to isolate the muscle that influences movements, our study focused on measuring the strength of flexor hallucis brevis and the abductor hallucis. Using ultrasound to measure the cross-sectional area of the abductor hallucis and flexor hallucis brevis, Latey et al. (2018) encountered a weak positive correlation between the cross-sectional area of abductor halux and toe strength measured with hand-held dynamometry and a strong and significant correlation with pedobarography. The cross-sectional area of flexor hallucis brevis and strength of this muscle measured by hand-held dynamometry and pedobarography was weak and non-significant. This study did not correlate with general foot mobility. Koyama et al. (2018) found a significant greater foot's intrinsic muscle strength in judo athletes than match controls, but the thickness of all foot intrinsic muscles did not significantly differ between groups.

On the other hand, Xiao et al. (2020) encountered a positive correlation between toe/metatarsophalangeal joint flexor strength and foot length, foot width, and truncated foot length. This author used a different methodology than we used. The focus of this study was to correlate the foot's morphology and strength. The strength was measured with different methods. Our principal focus was on foot mobility, not only morphology.

While in our study the objective was to investigate the relationship between strength and mobility, our results are different from other studies whose objectives are to investigate the relationship between strength and morphology/structure. Despite these different objectives, our mobility findings are similar to results encountered by McPoill et al. (2009).

The results of the present observational cross-sectional study raise the question of whether there is a relationship between strength and mobility. Some authors demonstrated that asymptomatic persons for lower limb injuries with a pronated foot could present more thick intrinsic muscles compared to pronated with injuries in lower limbs (ZHANG et al., 2019). Because one of the causes of the pronated foot is the elevated foot's mobility, we decided to investigate this relationship with methods of easy applicability in practice clinics in recreational runners. This could compensate for structural deficits during tasks with weight-bearing. 
Another important result of our study is the contribution in emphasizing that based on experimental conditions, the structure/morphology is not associated with performance of strength development. Complementary works are done in our laboratory to investigate the kinematic performance from these segments in this population.

Although our results in this population did not demonstrate an association between strength and mobility, further studies are necessary to elucidate this association in runners with musculoskeletal injuries in lower limbs. Patellofemoral pain syndrome is the most common injury in recreational runners. Higher foot mobility in this population leads to higher pronation. The in-shoes foot orthoses it is the recommendation based on the consensus of specialist and evidence-based for those cases. However, a recent study (Matthews et al., 2020) demonstrated no significant difference between groups with greater foot mobility treated with exercises based on the hip approach and that match treated with foot in-shoes orthoses. It is necessary to investigate this relationship and evaluate if muscle strength it is greater in this population as a compensatory mechanism. It is unlikely that intervention in one of these variables will be able to produce results in another in multimodal treatment plans to prevent and treat running injuries because of the weakness of the association between these variables. Inferences should be made with caution.

\section{Limitations}

One possible limitation of our study is that the strength measurements were executed in a single day for each participant, and not in more days. A part of the data collection was carried out during the pandemic period, and we did not want to do multiple data collections to increase risk exposure for participants. Furthermore, we did not count right and left feet as single independent observations. Assumption an analysis of people rather than feet is a way to prevent spurious findings, preventing type I errors (Altman \& Bland, 1997; Menz, 2004).

\subsubsection{Conclusion}

In this sample with this method and experimental conditions, we found a weak association of the hallux flexion strength and foot mobility in recreational runners free from 
lower extremity injuries. Given the absence of a relationship in this specific population does not represent an absence of association in other samples. Further studies are necessary to investigate this relationship in other runners, and in symptomatic runners for lower extremity injuries.

\section{Conflict of interest}

None of the authors have any conflict of interest to disclose, financial or otherwise. 


\subsubsection{References}

Aibast, H., Okutoyi, P., Sigei, T., Adero, W., Chemjor, D., Ongaro, N., Fuku, N., Konstabel, K., Clark, C., Lieberman, D. E., \& Pitsiladis, Y. (2017). Foot Structure and Function in Habitually Barefoot and Shod Adolescents in Kenya. Current Sports Medicine Reports, 16(6), 448-458. https://doi.org/10.1249/JSR.0000000000000431

Allen, R., \& Gross, M. (2003). Toe Flexors Strength and Passive Extension Range of Motion of the First Metatarsophalangeal Joint in Individuals With Plantar Fasciitis. J Orthop Sports Phys Ther, 33(8), 468-478.

Altman, D. G., \& Bland, J. M. (1997). Statistics notes: units of analysis. British Medical Journal, 1874, 314.

Barton, C. J., Bonanno, D., Levinger, P., \& Menz, H. B. (2010). Foot and ankle characteristics in patellofemoral pain syndrome: a case control and reliability study. Journal of Orthopaedic \& Sports Physical Therapy, 40(5), 286-296.

Endo, M., Ashton-Miller, J. A., \& Alexander, N. B. (2002). Effects of age and gender on toe flexor muscle strength. Journals of Gerontology - Series A Biological Sciences and Medical Sciences, 57(6), 392-397. https://doi.org/10.1093/gerona/57.6.M392

Farris, D. J., Kelly, L. A., Cresswell, A. G., \& Lichtwark, G. A. (2019). The functional importance of human foot muscles for bipedal locomotion. Proceedings of the National Academy of Sciences of the United States of America, 116(5), 1645-1650.

https://doi.org/10.1073/pnas.1812820116

Francis, P., Whatman, C., Sheerin, K., Hume, P., \& Johnson, M. I. (2019). The proportion of lower limb running injuries by gender, anatomical location and specific pathology: A systematic review. Journal of Sports Science and Medicine, 18(1), 21-31.

Goldmann, J. P., Sanno, M., Willwacher, S., Heinrich, K., \& Brüggemann, G. P. (2013). The potential of toe flexor muscles to enhance performance. Journal of Sports Sciences, 31(4), 424-433. https://doi.org/10.1080/02640414.2012.736627

Keenan, A. M., Redmond, A. C., Horton, M., Conaghan, P. G., \& Tennant, A. (2007). The Foot Posture Index: Rasch Analysis of a Novel, Foot-Specific Outcome Measure. Archives of Physical Medicine and Rehabilitation, 88(1), 88-93.

https://doi.org/10.1016/j.apmr.2006.10.005

Kelly, L. A., Cresswell, A. G., Racinais, S., Whiteley, R., \& Lichtwark, G. (2014). Intrinsic foot muscles have the capacity to control deformation of the longitudinal arch. Journal of the Royal Society Interface, 11(93). https://doi.org/10.1098/rsif.2013.1188

Ker, R. F., Bennett, M. B., Bibby, S. R., Kester, R. C., \& Alexander, R. M. (1987). The spring in the arch of the human foot. Nature, 147-149.

Koyama, K., Hirokawa, M., Yoshitaka, Y., \& Yamauchi, J. (2019). Toe Flexor Muscle Strength and Morphological Characteristics of the Foot in Judo Athletes. International Journal of Sports Medicine, 40(4), 263-268. https://doi.org/10.1055/a-0796-6679 
Latey, P. J., Burns, J., Nightingale, E. J., Clarke, J. L., \& Hiller, C. E. (2018). Reliability and correlates of cross-sectional area of abductor hallucis and the medial belly of the flexor hallucis brevis measured by ultrasound. Journal of Foot and Ankle Research, 11(1), 1-11. https://doi.org/10.1186/s13047-018-0259-0

Lin, C., Ph, D., Lai, K., Kuan, T., Chou, Y., \& Ph, D. (2001). Correlating Factors and Clinical Significance of Flexible Flatfoot in Preschool Children. 378-382.

Lopes, A. D., Costa, L. O. P., Saragiotto, B. T., Yamato, T. P., Adami, F., \& Verhagen, E. (2011). Musculoskeletal pain is prevalent among recreational runners who are about to compete: An observational study of 1049 runners. Journal of Physiotherapy, 57(3), 179-182. https://doi.org/10.1016/S1836-9553(11)70039-X

Matthews, M., Rathleff, M. S., Claus, A., McPoil, T., Nee, R., Crossley, K. M., Kasza, J., \& Vicenzino, B. T. (2020). Does foot mobility affect the outcome in the management of patellofemoral pain with foot orthoses versus hip exercises? A randomised clinical trial. British Journal of Sports Medicine, 1-8. https://doi.org/10.1136/bjsports-2019-100935

McKeon, P. O., Hertel, J., Bramble, D., \& Davis, I. (2015). The foot core system: A new paradigm for understanding intrinsic foot muscle function. British Journal of Sports Medicine, 49(5), 290. https://doi.org/10.1136/bjsports-2013-092690

McPoil, T. G., Vicenzino, B., Cornwall, M. W., Collins, N., \& Warren, M. (2009). Reliability and normative values for the foot mobility magnitude: A composite measure of vertical and medial-lateral mobility of the midfoot. Journal of Foot and Ankle Research, 2(1), 1-12. https://doi.org/10.1186/1757-1146-2-6

McPoil, T. G., Warren, M., Vicenzino, B., \& Cornwall, M. W. (2011). Variations in foot posture and mobility between individuals with patellofemoral pain and those in a control group. Journal of the American Podiatric Medical Association, 101(4), 289-296. https://doi.org/10.7547/1010289

Menz, H. B. (2004). Two feet, or one person? Problems associated with statistical analysis of paired data in foot and ankle medicine. The Foot, 14(1), 2-5. https://doi.org/10.1016/S0958$\underline{\text { 2592(03)00047-6 }}$

Morita, N., Yamauchi, J., Kurihara, T., Fukuoka, R., Otsuka, M., Okuda, T., Ishizawa, N., Nakajima, T., Nakamichi, R., Matsuno, S., Kamiie, S., Shide, N., Kambayashi, I., \& Shinkaiya, H. (2015). Toe flexor strength and foot arch height in children. Medicine and Science in Sports and Exercise, 47(2), 350-356.

https://doi.org/10.1249/MSS.0000000000000402

Quek, J., Treleaven, J., Brauer, S. G., O’Leary, S., \& Clark, R. A. (2015). Intra-rater reliability of hallux flexor strength measures using the Nintendo Wii Balance Board. Journal of Foot and Ankle Research, 8(1), 1-5. https://doi.org/10.1186/s13047-015-0104-7

Redmond, A. C., Crosbie, J., \& Ouvrier, R. A. (2006). Development and validation of a novel rating system for scoring standing foot posture: The Foot Posture Index. Clinical Biomechanics, 21(1), 89-98. https://doi.org/10.1016/j.clinbiomech.2005.08.002 
Soysa, A., Hiller, C. E., \& Refshauge, K. M. (2012). Importance and challenges of measuring intrinsic foot muscle strength. July 2014. https://doi.org/10.1186/1757-1146-5-29

Sulowska, I., Mika, A., Oleksy, Ł., \& Stolarczyk, A. (2019). The Influence of Plantar Short Foot Muscle Exercises on the Lower Extremity Muscle Strength and Power in Proximal Segments of the Kinematic Chain in Long-Distance Runners. BioMed Research International, 2019. https://doi.org/10.1155/2019/6947273

Venkadesan, M., Yawar, A., Eng, C. M., Dias, M. A., Singh, D. K., Tommasini, S. M., Haims, A. H., Bandi, M. M., \& Mandre, S. (2020). Stiffness of the human foot and evolution of the transverse arch. Nature, 579(7797), 97-100. https://doi.org/10.1038/s41586-020-2053y

Xiao, S., Zhang, X., Deng, L., Zhang, S., Cui, K., \& Fu, W. (2020). Relationships between foot morphology and foot muscle strength in healthy adults. International Journal of Environmental Research and Public Health, 17(4). https://doi.org/10.3390/ijerph17041274

Zhang, X., Pauel, R., Deschamps, K., Jonkers, I., \& Vanwanseele, B. (2019). Differences in foot muscle morphology and foot kinematics between symptomatic and asymptomatic pronated feet. Scandinavian Journal of Medicine and Science in Sports, 29(11), 1766-1773. https://doi.org/10.1111/sms.13512 


\subsection{Resultados estudo 2}

\subsubsection{Results}

There were not identified a statistically significant difference between groups for the movement of the shank in the transverse plane $(\mathrm{Z})$, and for the rearfoot in the frontal plane $(\mathrm{Y})$ during the stance phase of running (Figure 2). A statistically significant difference was reported between groups for the relative frequency of occurrence of the coordination pattern for antiphase coordination with distal dominance, and for in-phase coordination with distal dominance (Figure 3). Anti-phase coordination with distal dominance was greater in CG (19\%) than PFPG $(7 \%)(\mathrm{p}=0.021, \mathrm{CI}=0.018$ to 0.222 , effect size $=1.080$ [large]). In phase coordination with distal dominance was greater in PFPG (28\%) than CG (12\%) ( $\mathrm{p}=0.008, \mathrm{CI}=-0.279$ to -0.041 , effect size $=0.407$ [small]). It was identified a statistical significance difference between groups for the vector coding analysis around $75 \%$ of the stance phase $(p=0.036)$ (Figure 4).

(a)

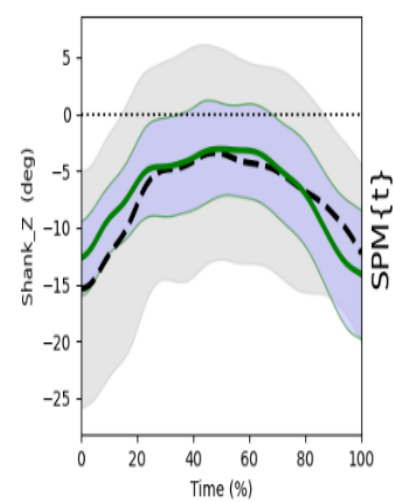

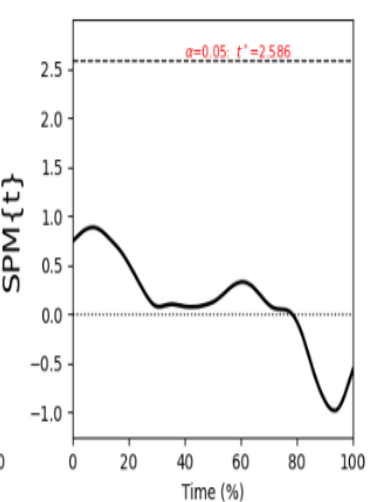

(b)

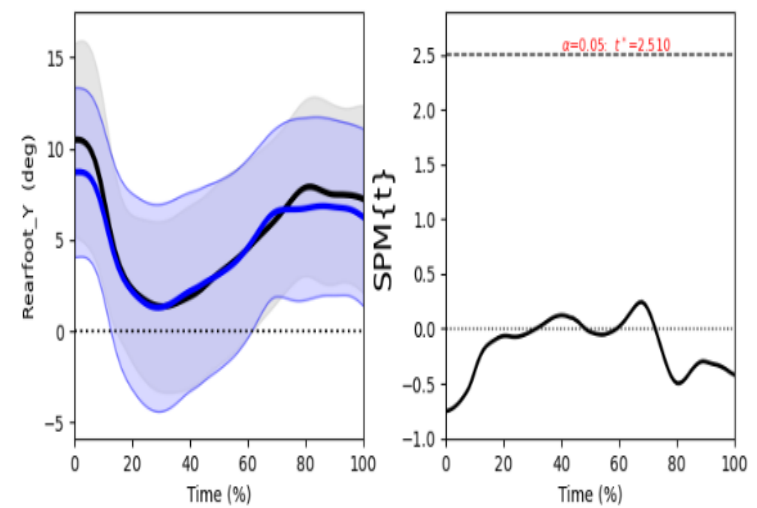

Figure 02. Plots of Statistical Parametric Mapping. (a) The comparing between CG and PFPG for shank in the transverse plane $(\mathrm{Z})(\mathrm{CG}=$ green line; $\mathrm{PFPG}=$ dashed black line $)$. (b) The comparing between $\mathrm{CG}$ and PFPG for rearfoot in the frontal plane $(\mathrm{Y})(\mathrm{CG}=$ blue line; $\mathrm{PFPG}=$ continue black line $)$. 


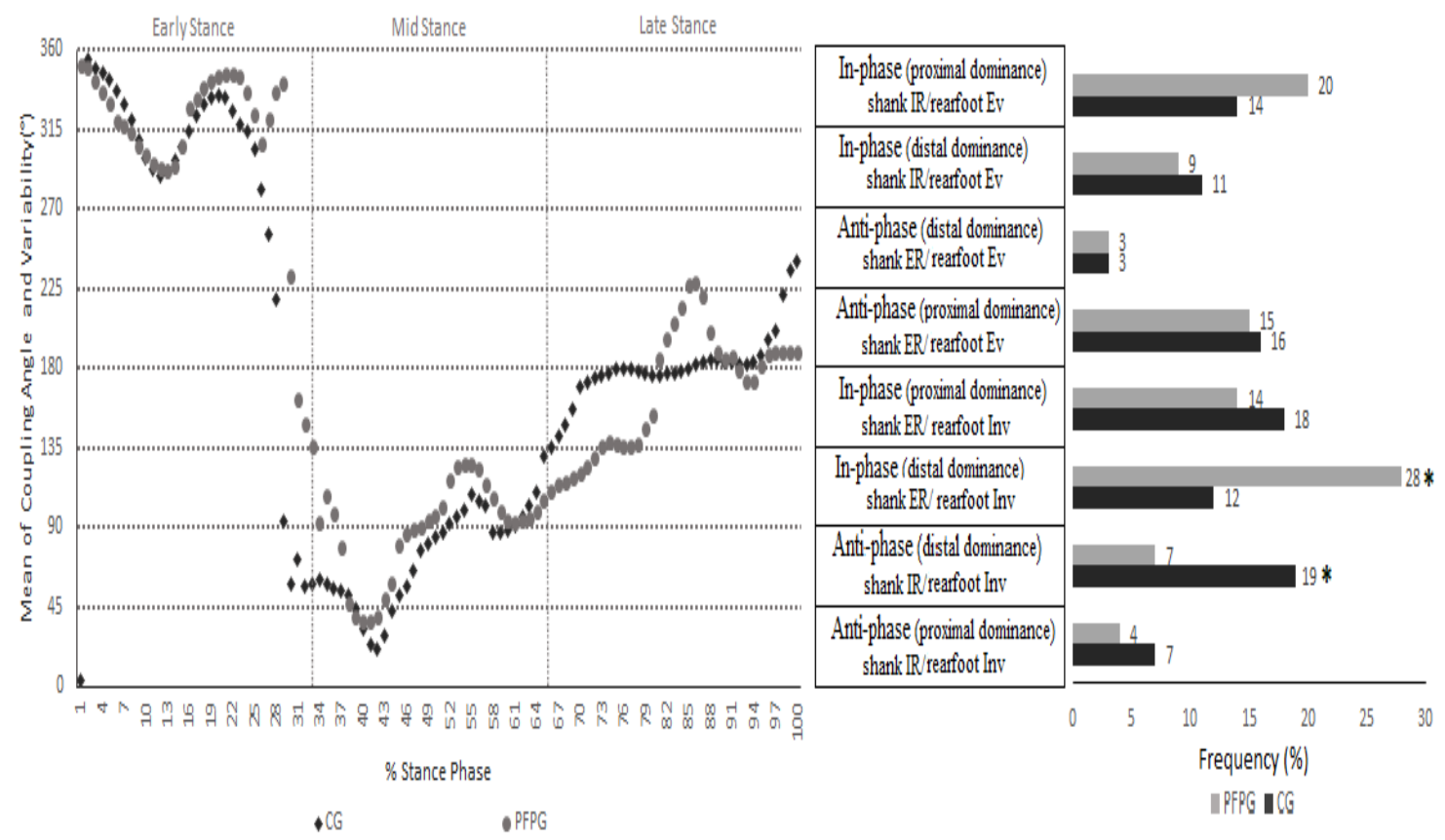

Figure 03. Mean of Coupling Angle during the stance phase of running (left side) (black triangle $=$ Control Group; grey circle $=$ PFPG). Relative frequency of each of the Coordination Pattern $(* p<0.05)$.
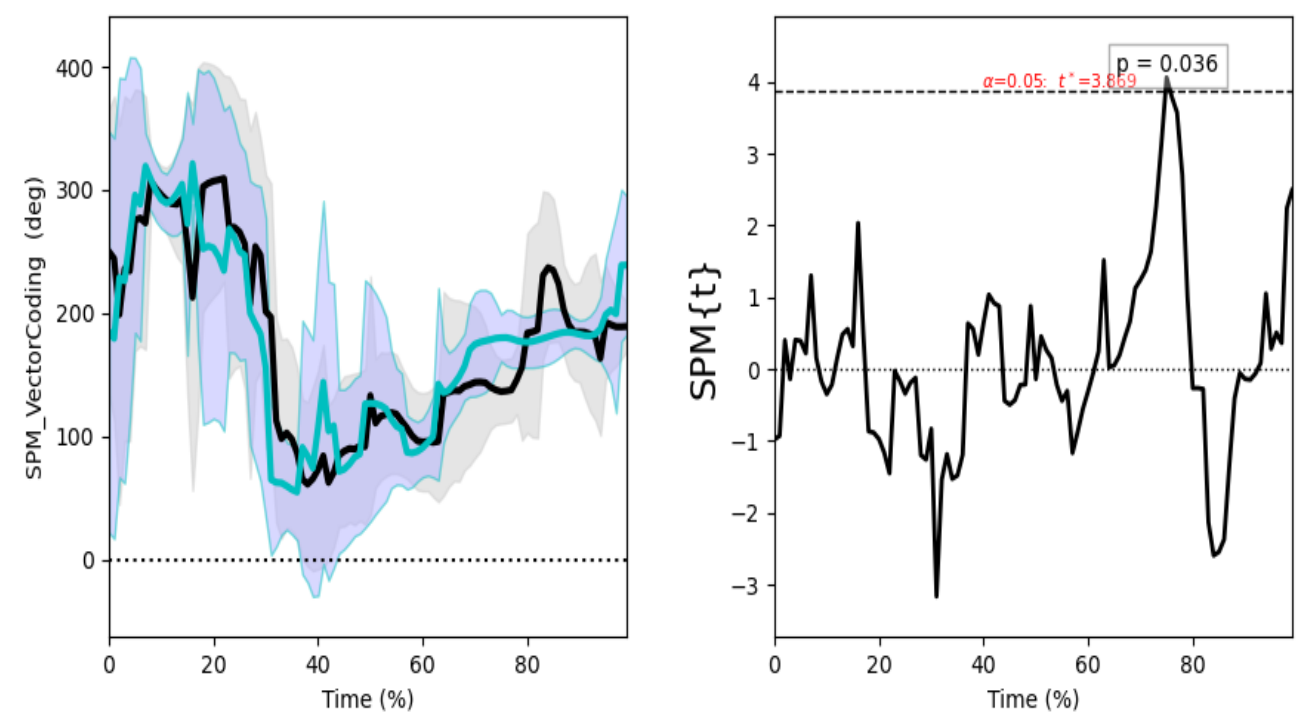

Figure 04. Statistical parametric mapping on Vector Coding (left side: solid cyan line = CG; solid black line = PFPG). 


\subsubsection{Discussion}

The present study investigated the difference of movement for the shank in the transverse plane $(\mathrm{Z})$, rearfoot in the frontal plane $(\mathrm{Y})$, and the movement coordination pattern between these segments among recreational runners free from injuries in lower extremities, and those with patellofemoral pain syndrome. The main findings were that there was no statistically significant difference between groups for the movement of the shank in the transverse plane, and for the rearfoot in the frontal plane. However, the relations between these segments resulted in different movement coordination patterns in different phases of the stance. The anti-phase coordination with distal dominance of rearfoot inversion at the midstance phase was significantly greater in the control group than in the patellofemoral pain group (PFPG). The inphase coordination with distal dominance of rearfoot inversion was greater in the PFPG during propulsion, but with a small effect size.

The result of the study showed that if we only look at the discrete continue movement, we can incurrence in error to affirm that there is no difference between these individuals. The findings from this study showed partial accordance with previous studies (Bramah et al., 2018; Luz et al., 2018; Noehren et al., 2012). In our study, the discrete continue movement of the shank in the transverse plane did not differ between health recreational runners and those runners with PFP (Figure 2 - a), similarly to that encountered by Luz et al. 2018. On the other hand, our results differ from those reported by Noehren et al. (2012). This author related greater movement of shank internal rotation in individuals with PFPS. With respect to rearfoot eversion, our findings were similar to those reported by Noehren et al. (2012), and Luz et al. (2018). There was no difference between groups (Figure $2-b$ ). However, our findings were different from those results reported by Bramah et al. (2018), which reported statistical significance difference of rearfoot movement. A direct comparison between our study and others should be made with caution. If these studies looked at the peak of angular movement, we opted to use statistical parametric mapping. This is a methodology for topological analysis of continuous changes in time series of kinetic-kinematic data (Pataky, 2012). The statistical result for time-series data it is a time-series too, allowing for a better interpretation of the data (Serrien, Goossens and Baeyens, 2019). It was evident that although there was no difference in kinematic topological data for shank and rearfoot when they were analyzed separately, the movement coordination pattern between than differed between groups in different phases of stance. 
Movement coordination pattern is a process in which the multiple degrees of freedom of the segments are in proper relation (Turvey, 1990). The coupling means that the motion of one segment can influence the motion of another segment (Hamill et al., 2012). In our study, in the first $1 / 3$ of the stance phase (see figure 3), both groups showed a coordination pattern in phase with shank internal rotation and rearfoot eversion. In this contact phase, it is known that the knee automatically flexes around 15 to $20^{\circ}$, synchronously of shank internal rotation and rearfoot eversion (Tiberio, 1987). After this phase, the control group showed at $30-52 \%$ of midstance, a greater prevalence of coupling angles that resulted in coordination pattern antiphase with distal dominance of the movement of rearfoot inversion. This pattern was with statistical significance difference and showed a large effect size. In this phase, the rearfoot starts reversing or changing from eversion to inversion movement, when the shank still remains internally rotating (see figure 3). This pattern progress and culminates with the presence of shank external rotation around the starts of the propulsion phase, which was prevalent for the last $1 / 3$ of the propulsion phase. Therefore, it is possible that the movement of the rearfoot inversion could be interpreted as the ignition of the shank external rotation. At the propulsion phase, there was a statistically significant difference observed in SPM around $75 \%$ of this phase (see figure 4). The pattern was predominantly in a coupling angle of $180^{\circ}$, with coordination it was characterized in-phase pattern with shank external rotation (almost exclusively), and rearfoot inversion. In the propulsion phase, although the patellofemoral group showed a predominance of the in-phase movement too, the coordination was with the prevalence of the rearfoot inversion, supposing that the tíbia did not external rotated enough. Although it was not the scope of our research, it is tempting to suppose that this pattern presented by the PFPG could be a consequence of the deficit of hip external rotators. So, the occurrence of this distinct coordination in the respective phases of the stance seems to be phase-dependent.

The distinct movement coordination patterns in different moments of the stance phase can be a consequence of the range of motion of the segments, or the timing of occurrence of this movement (Mcclay and Manal, 1997). In our study, the distal movement of the rearfoot inversion prevalence in midstance, supposing that the inversion rotated more than the shank. Furthermore, when we observed figure 3 , we saw that at $28 \%$ of the stance phase it was already verified the presence of this pattern, supposing a difference in the timing of occurrence of this pattern. This pattern occurred early in the control group. Furthermore, it may be possible that the rearfoot started inversion earlier in the control group than PFPG. If we observe the inclination of the curve around the start of the propulsion phase (figure 3), it may be possible that the occurrence of this pattern in the control group occurred more rapidly than the PFPG. 
The different patterns observed corroborated the link of rearfoot inversion and shank external rotation. It is postulated that structural and postural alterations in the foot can cause higher stress in the patellofemoral joint (Powers et al., 2017). Based on our results, it is the interaction between segments resulting in different movement coordination patterns a possible risk factor for symptoms in the patellofemoral joint. The in-phase coordination in the first $1 / 3$ of the stance phase, and shank internal rotation in the midstance, maybe a strategy to soften abnormal loading of the patellofemoral joint, i.e. elevated joint stress. Thus, it seems salutary to think, that in rehabilitation and performance improvement programs, it is necessary to train different coordination patterns depending on the phase of execution of the task. However, studies demonstrated that it is difficult to extrapolate the alignment retraining in tasks such as climbing and step-up and down to more dynamic activities such as walking and running (Willy, 2011). Furthermore, it is an international consensus that the pathogenesis of the patellofemoral pain syndrome is multifactorial and largely unknown (Crossley et al., 2019). The treatment strategies may be multimodal. From the perspective of the biomechanical approach, our results can bring some insights about the paradigm of movement coordination pattern, or the relation of shank and rearfoot at the special population of runners with symptoms in patellofemoral joint

Knowledge of the movement coordination pattern does not imply knowing which is the best or worst pattern. Furthermore, it does not mean establishing hierarchies between these standards. Knowledge of the movement coordination pattern implies a better approach in rehabilitation processes, improved performance in sports activities, among other objectives. Our results had shown that in a dynamic task such as running, a pattern in phase in the contact phase is frequent. The internal rotation of the leg with eversion of the calcaneus in this phase can be a strategy to accommodate the loads. Internal tibial rotation prevails during midstance, but now in an anti-phase pattern. In this phase, there is a prevalence of rearfoot inversion. During propulsion, there is again a pattern in phase, but now with a predominance of external tibial rotation and inversion of the calcaneus. Thus, rehabilitation and performance improvement programs should take into account all these patterns of movement coordination pattern in distinct subphases of the stance, and not the hegemony of one at the expense of the other. In addition, the importance of the knowledge acquired regarding the importance of the movement of the rearfoot in this group of runners with patellofemoral symptoms was evident.

This observational study has limitations. One of them concerns the fact that the participants performed the experiment barefoot. Although it is a way of directly observing the behavior of the multiple segments of the foot during the run, different behaviors of these segments can happen when running with tennis. Running barefoot can lead to changes in the 
usual running pattern, but all runners showed to be heel footstrike. We did not measure results in runners with a midfoot strike or forefoot strike pattern. Thus, extrapolations and generalizations of these results should be made with caution. Another important point concerns the speed of the run. We opted for this protocol because it is an intermediate speed so that the study was not limited to the analysis of walking alone, but also so that the speed of execution of the running was not high enough to mitigate the usual running pattern of the participants. Despite these limitations, we believe that we can provide some clarifications regarding the biomechanics of running in recreational runners with patellofemoral pain. 


\subsubsection{Conclusions}

The evidence of our study suggest that the movement of the shank in the transverse plane, and rearfoot in the frontal plane do not differ signicantly between groups of health runners, and those runners with PFP. However, in phase coordination with distal dominance was greater in CG than PFPG, and anti phase coordination with distal dominance was greater in PFPG than CG. The greater in phase coordinaiton and distal dominance in this dinamical and cyclical task displayed by the control group during the stance phase suggest an better coordinative and adaptative mechanism to the loads in the health controls runners. The intereaction between segments resulting in differents movement coordination patterns it seams to be more importante than discrete continuous movement of these segments.

\section{Acknowledgements:}

Grants \#2010/20538-7, São Paulo Research Foundation (FAPESP); \#432259/2018-0, Conselho Nacional de Desenvolvimento Científico e Tecnológico (CNPq); Coordenação de Aperfeiçoamento de Pessoal de Nível Superior - Brasil (CAPES) - Finance Code 001; University of São Paulo (USP) - Finance code 19125 \#19.1.359.90.4. 


\subsubsection{References}

ARNOLD, John B.; CARAVAGGI, Paolo; FRAYSSE, François; et al. Movement coordination patterns between the foot joints during walking. Journal of Foot and Ankle Research, v. 10, n. 1, p. 1-7, 2017.

BARTON, Christian J; BONANNO, Daniel; LEVINGER, Pazit; et al. Foot and ankle characteristics in patellofemoral pain syndrome: a case control and reliability study. journal of orthopaedic \& sports physical therapy, v. 40, n. 5, p. 286-296, 2010.

BRAMAH, Christopher; PREECE, Stephen J; GILL, Niamh; et al. Is There a Pathological Gait Associated With Common Soft Tissue Running Injuries? Am J Sports Med, v. 46, n. 12, p. 3023-3031, 2018.

CHANG, Ryan; VAN EMMERIK, Richard; HAMILL, Joseph. Quantifying rearfoot-forefoot coordination in human walking. Journal of Biomechanics, v. 41, n. 14, p. 3101-3105, 2008.

CROSSLEY, K. M.; VAN MIDDELKOOP, Marienke; BARTON, Christian J.; et al. Rethinking patellofemoral pain: Prevention, management and long-term consequences. Best Practice and Research: Clinical Rheumatology, v. 33, n. 1, p. 48-65, 2019. Disponível em: $<$ https://doi.org/10.1016/j.berh.2019.02.004>.

CROSSLEY, Kay M.; MIDDELKOOP, Marienke Van; CALLAGHAN, Michael J.; et al. 2016 Patellofemoral pain consensus statement from the 4th International Patellofemoral Pain Research Retreat, Manchester. Part 2: Recommended physical interventions (exercise, taping, bracing, foot orthoses and combined interventions). British Journal of Sports Medicine, v. 50, n. 14, p. 844-852, 2016.

CUNNINGHAM, Tommy J; MULLINEAUX, David R; NOEHREN, Brian; et al. Clinical Biomechanics Coupling angle variability in healthy and patellofemoral pain runners. JCLB, v. 29, n. 3, p. 317-322, 2014. Disponível em:

<http://dx.doi.org/10.1016/j.clinbiomech.2013.12.008>.

FORD, Kevin R.; MYER, Gregory D.; HEWETT, Timothy E. Valgus knee motion during landing in high school female and male basketball players. Medicine and Science in Sports and Exercise, v. 35, n. 10, p. 1745-1750, 2003.

FRANCIS, Peter; WHATMAN, Chris; SHEERIN, Kelly; et al. The proportion of lower limb running injuries by gender, anatomical location and specific pathology: A systematic review. Journal of Sports Science and Medicine, v. 18, n. 1, p. 21-31, 2019.

HAMILL, Joseph; PALMER, Christopher; VAN EMMERIK, Richard E.A. Coordinative variability and overuse injury. Sports Medicine, Arthroscopy, Rehabilitation, Therapy and Technology, v. 4, n. 1, p. 1-9, 2012.

LOPES, Alexandre Dias; COSTA, Leonardo Oliveira Pena; SARAGIOTTO, Bruno Tirotti; et al. Musculoskeletal pain is prevalent among recreational runners who are about to compete: An observational study of 1049 runners. Journal of Physiotherapy, v. 57, n. 3, p. 179-182, 2011. Disponível em: 〈http://dx.doi.org/10.1016/S1836-9553(11)70039-X>. 
LUZ, Bruna Calazans; DOS SANTOS, Ana Flávia; DE SOUZA, Mariana Carvalho; et al. Relationship between rearfoot, tibia and femur kinematics in runners with and without patellofemoral pain. Gait and Posture, v. 61, p. 416-422, 2018. Disponível em: <http://dx.doi.org/10.1016/j.gaitpost.2018.02.008>.

MCCLAY, Irene; MANAL, Kurt. Coupling Parameters in Runners With Normal and Excessive Pronation. Journal of Applied Biomechanics, v. 13, n. 1989, p. 109-124, 1997.

MCPOIL, Thomas G.; WARREN, Meghan; VICENZINO, Bill; et al. Variations in foot posture and mobility between individuals with patellofemoral pain and those in a control group. Journal of the American Podiatric Medical Association, v. 101, n. 4, p. 289-296, 2011.

NEAL, Bradley S; BARTON, Christian J; GALLIE, Rosa; et al. Gait \& Posture Runners with patellofemoral pain have altered biomechanics which targeted interventions can modify : A systematic review and meta-analysis. Gait \& Posture, v. 45, p. 69-82, 2016. Disponível em: <http://dx.doi.org/10.1016/j.gaitpost.2015.11.018>.

NEEDHAM, Robert A; NAEMI, Roozbeh; CHOCKALINGAM, Nachiappan. Short communication A new coordination pattern classi fi cation to assess gait kinematics when utilising a modi fi ed vector coding technique. Journal of Biomechanics, v. 48, n. 12, p. 3506-3511, 2015. Disponível em: 〈http://dx.doi.org/10.1016/j.jbiomech.2015.07.023>.

NOEHREN, Brian; POHL, Michael B.; SANCHEZ, Zack; et al. Proximal and distal kinematics in female runners with patellofemoral pain. Clinical Biomechanics, v. 27, n. 4, p. 366-371, 2012. Disponível em: 〈http://dx.doi.org/10.1016/j.clinbiomech.2011.10.005>.

POHL, Michael B; MESSENGER, Neil; BUCKLEY, John G. Forefoot , rearfoot and shank coupling : Effect of variations in speed and mode of gait. v. 25, p. 295-302, 2007.

POWERS, Christopher M.; WITVROUW, Erik; DAVIS, Irene S.; et al. Evidence-based framework for a pathomechanical model of patellofemoral pain: 2017 patellofemoral pain consensus statement from the 4th International Patellofemoral Pain Research Retreat, Manchester, UK: Part 3. British Journal of Sports Medicine, v. 51, n. 24, p. 1713-1723, 2017. Disponível em: <http://bjsm.bmj.com/>.

POWERS, Christopher M. The influence of altered lower-extremity kinematics on patellofemoral joint dysfunction: a theoretical perspective. Journal of Orthopaedic \& Sports Physical Therapy, v. 33, n. 11, p. 639-646, 2003.

RODRIGUES, Pedro; CHANG, Ryan; TENBROEK, Trampas; et al. Evaluating the Coupling Between Foot Pronation and Tibial Internal Rotation Continuously Using Vector Coding. n. 1, p. 88-94, 2015.

SERRIEN, Ben; GOOSSENS, Maggy; BAEYENS, Jean Pierre. Statistical parametric mapping of biomechanical one-dimensional data with Bayesian inference. International Biomechanics, v. 6, n. 1, p. 9-18, 2019. Disponível em: <https://doi.org/10.1080/23335432.2019.1597643>. 
TIBERIO, David. The effect of excessive subtalar joint pronation on patellofemoral mechanics: a theoretical model. Journal of Orthopaedic \& Sports Physical Therapy, v. 9, n. 4, p. 160-165, 1987.

WILLY, Richard W. The Effect of a Hip-Strengthening Program on Mechanics During Running and During a Single-Leg Squat. v. 41, n. 9, p. 625-632, 2011.

WITVROUW, Erik; CALLAGHAN, Michael J.; STEFANIK, Joshua J.; et al. Patellofemoral pain: Consensus statement from the 3rd International Patellofemoral Pain Research Retreat held in Vancouver, September 2013. British Journal of Sports Medicine, v. 48, n. 6, p. 411414, 2014.

ZENI, J.A.; RICHARDS, J.G.; HIGGINSON, J.S. Two simple methods for determining gait events during treadmill and overground walking using kinematic data. Gait Posture, v. 27, n. 4, p. 710-714, 2008. 


\section{CONSIDERAÇÕES FINAIS}

O documento apresentado originou-se de dúvidas, questionamentos e perguntas suscitadas no dia-dia da prática clínica do fisioterapeuta, de profissionais em educação física, corredores recreacionais ou até mesmo corredores de alta performance, dentre outros envolvidos no manejo de questões relacionadas ao estudo do movimento humano. Embora os objetivos não tivessem diretamente concatenados nos dois estudos, nossos resultados permitiram, de uma maneira incipiente, um entendimento inicial sistêmico de algumas questões relacionadas à força da flexão plantar do hálux e a mobilidade do pé. Além disso, possibilitou um entendimento do padrão de coordenação do movimento entre o retropé e a perna em corredores recreacionais com dor femoropatelar.

Os resultados desta dissertação mostram, inicialmente, que não há forte associação em nenhuma direção das mensurações de força de flexão do hálux e a mobilidade geral do pé em indivíduos assintomáticos para lesões musculoesqueléticas em membros inferiores. Talvez a ausência de forte associação em qualquer direção seja devido ao fato de a população analisada ser assintomática para lesões musculoesqueléticas. Para mensurar a mobilidade, optamos por um método simples, de baixo custo, reprodutível e já validado, e que pudesse ser usado na prática clínica. A força de flexão plantar do hálux também foi realizada com base em métodos presentes em estudos que deram origem a trabalhos científicos apresentados no transcorrer do texto da dissertação. Embora não foi verificado associação, este fato não exime o clínico de executar as medidas, mas o subtrai de pensar numa forte associação entre as mensurações. Estudos futuros com outro desenho experimental e outras populações com características diferentes ou mesmo com lesões musculoesqueléticas, podem apresentar resultados diferentes dos apresentados nesta dissertação. Além disso, o uso destes métodos abre novos horizontes de pesquisa e pode propiciar investigações e responder outras questões de pesquisa com objetivos distintos dos apresentados nesta dissertação. Os resultados da associação das variáveis apresentados neste documento devem ser extrapolados com cautela porque incialmente analisamos apenas corredores assintomáticos para lesões musculoesqueléticas nos membros inferiores. Estudos futuros com populações especiais são necessários para investigar as mensurações consideradas dicotômicas do ponto de vista mecânico entre mobilidade e força .

A dissertação também mostra que em corredores recreacionais assintomáticos para lesões musculoesqueléticas nos membros inferiores e naqueles com dor femoropatelar as 
variáveis cinemáticas estudadas dos movimentos da perna e do retropé não diferem entre os grupos. Entretanto, a interação entre elas resulta em padrões de coordenação de movimentos diferentes. $\mathrm{O}$ padrão de coordenação de movimento parece ser mais importante que a análise dos movimentos isolados dos segmentos. Muito mais que apenas corrigir e alterar movimentos de segmentos isolados, os resultados desta dissertação fomentam mais perguntas sobre estratégias de intervenção com vistas à melhoria de performance e prevenção de lesões. 


\section{REFERÊNCIAS}

BARTON, Christian J.; BONANNO, Daniel; LEVINGER, Pazit; MENZ, Hylton B. Foot and ankle characteristics in patellofemoral pain syndrome: a case control and reliability study. journal of orthopaedic \& sports physical therapy, [S. l.], v. 40, n. 5, p. 286-296, 2010.

BOLING, M. C. et al. A prospective investigation of biomechanical risk factors for patellofemoral pain syndrome: the Joint Undertaking to Monitor and Prevent ACL Injury (JUMP-ACL) cohort. The American journal of sports medicine, v. 37, n. 11, p. 2108-2116, 2009.

CROSSLEY, K. M.; VAN MIDDELKOOP, Marienke; BARTON, Christian J.; CULVENOR, Adam G. Rethinking patellofemoral pain: Prevention, management and long-term consequences. Best Practice and Research: Clinical Rheumatology, [S. l.], v. 33, n. 1, p. 48-65, 2019. DOI: 10.1016/j.berh.2019.02.004. Disponível em: https://doi.org/10.1016/j.berh.2019.02.004.

CROSSLEY, Kay M. et al. 2016 Patellofemoral pain consensus statement from the 4th International Patellofemoral Pain Research Retreat, Manchester. Part 1: Terminology, definitions, clinical examination, natural history, patellofemoral osteoarthritis and patientreported outcome m. British Journal of Sports Medicine, [S. l.], v. 50, n. 14, p. 839-843, 2016. DOI: 10.1136/bjsports-2016-096384.

FARRIS, Dominic James; KELLY, Luke A.; CRESSWELL, Andrew G.; LICHTWARK, Glen A. The functional importance of human foot muscles for bipedal locomotion.

Proceedings of the National Academy of Sciences of the United States of America, [S. l.], v. 116, n. 5, p. 1645-1650, 2019. DOI: 10.1073/pnas.1812820116.

FRANCIS, Peter; WHATMAN, Chris; SHEERIN, Kelly; HUME, Patria; JOHNSON, Mark I. The proportion of lower limb running injuries by gender, anatomical location and specific pathology: A systematic review. Journal of Sports Science and Medicine, [S. l.], v. 18, n. 1, p. 21-31, 2019.

GOLDMANN, Jan Peter; BRÜGGEMANN, Gert Peter. The potential of human toe flexor muscles to produce force. Journal of Anatomy, [S. l.], v. 221, n. 2, p. 187-194, 2012. DOI: 10.1111/j.1469-7580.2012.01524.x.

HICKS, J.H. The mechanics of the foot. II. The plantar aponeurosis and the arch. Journal of Anatomy. v. 88, p. 25-30, 1954. Disponivel em: https://www.ncbi.nlm.nih.gov/pmc/articles/PMC1244640/?page=4

KELLY, Luke A.; CRESSWELL, Andrew G.; RACINAIS, Sebastien; WHITELEY, Rodney; LICHTWARK, Glen. Intrinsic foot muscles have the capacity to control deformation of the longitudinal arch. Journal of the Royal Society, Interface, [S. l.], v. 11, n. 93, p. 20131188, 2014. DOI: 10.1098/rsif.2013.1188. Disponível em: http://www.ncbi.nlm.nih.gov/pubmed/24478287. Acesso em: 17 jun. 2020.

LEARDINI, A., et al. Rear-foot, Mid-foot and Fore-foot Motion during the Stance Phase of Gait. Gait and Posture. v. 25, p.453-55, 2007. 
LIN, Chii-jeng; PH, D.; LAI, Kuo-an; KUAN, Ta-shen; CHOU, You-li; PH, D. Correlating Factors and Clinical Significance of Flexible Flatfoot in Preschool Children. [S. l.], p. 378$382,2001$.

LOPES, Alexandre Dias; COSTA, Leonardo Oliveira Pena; SARAGIOTTO, Bruno Tirotti; YAMATO, Tiê Parma; ADAMI, Fernando; VERHAGEN, Evert. Musculoskeletal pain is prevalent among recreational runners who are about to compete: An observational study of 1049 runners. Journal of Physiotherapy, [S. l.], v. 57, n. 3, p. 179-182, 2011. DOI: 10.1016/S1836-9553(11)70039-X. Disponível em: http://dx.doi.org/10.1016/S18369553(11)70039-X.

LUZ, Bruna Calazans; DOS SANTOS, Ana Flávia; DE SOUZA, Mariana Carvalho; DE OLIVEIRA SATO, Tatiana; NAWOCZENSKI, Deborah A.; SERRÃO, Fábio Viadanna. Relationship between rearfoot, tibia and femur kinematics in runners with and without patellofemoral pain. Gait and Posture, [S. l.], v. 61, p. 416-422, 2018. DOI: 10.1016/j.gaitpost.2018.02.008. Disponível em: http://dx.doi.org/10.1016/j.gaitpost.2018.02.008.

MCKEON, Patrick O.; HERTEL, Jay; BRAMBLE, Dennis; DAVIS, Irene. The foot core system: A new paradigm for understanding intrinsic foot muscle function. British Journal of Sports Medicine, [S. l.], v. 49, n. 5, p. 290, 2015. DOI: 10.1136/bjsports-2013-092690.

MCPOIL, Thomas G.; WARREN, Meghan; VICENZINO, Bill; CORNWALL, Mark W. Variations in foot posture and mobility between individuals with patellofemoral pain and those in a control group. Journal of the American Podiatric Medical Association, [S. l.], v. 101, n. 4, p. 289-296, 2011. DOI: 10.7547/1010289.

\section{MINISTÉRIO DO ESPORTE. Diagnóstico Nacional do Esporte: caderno 1Diagnóstico} Nacional do Esporte - Caderno I. [s.l: s.n.]. Disponível em: www.esporte.gov.br/diesporte.

NOEHREN, Brian; POHL, Michael B.; SANCHEZ, Zack; CUNNINGHAM, Tom; LATTERMANN, Christian. Proximal and distal kinematics in female runners with patellofemoral pain. Clinical Biomechanics, [S. l.], v. 27, n. 4, p. 366-371, 2012. DOI: 10.1016/j.clinbiomech.2011.10.005. Disponível em: http://dx.doi.org/10.1016/j.clinbiomech.2011.10.005.

POWERS, Christopher M. The influence of altered lower-extremity kinematics on patellofemoral joint dysfunction: a theoretical perspective. Journal of Orthopaedic \& Sports Physical Therapy, [S. l.], v. 33, n. 11, p. 639-646, 2003.

POWERS, Christopher M.; WITVROUW, Erik; DAVIS, Irene S.; CROSSLEY, Kay M. Evidence-based framework for a pathomechanical model of patellofemoral pain: 2017 patellofemoral pain consensus statement from the 4th International Patellofemoral Pain Research Retreat, Manchester, UK: Part 3. British Journal of Sports Medicine, [S. l.], v. 51, n. 24, p. 1713-1723, 2017. DOI: 10.1136/bjsports-2017-098717. Disponível em: http://bjsm.bmj.com/.

SULOWSKA, Iwona; MIKA, Anna; OLEKSY, Łukasz; STOLARCZYK, Artur. The Influence of Plantar Short Foot Muscle Exercises on the Lower Extremity Muscle Strength 
and Power in Proximal Segments of the Kinematic Chain in Long-Distance Runners. BioMed Research International, [S. l.], v. 2019, 2019. DOI: 10.1155/2019/6947273.

TADDEI UT, MATIAS AB, RIBEIRO FIA, BUS SA, SACCO ICN. Effects of a foot strengthening program on foot muscle morphology and running mechanics: A proof-ofconcept, single-blind randomized controlled trial. Phys Ther Sport. 2020 Mar;42:107-115. doi: 10.1016/j.ptsp.2020.01.007. Epub 2020 Jan 13. PMID: 31962191.

TADDEI UT, MATIAS AB, DUARTE M, SACCO ICN. Foot Core Training to Prevent Running-Related Injuries: A Survival Analysis of a Single-Blind, Randomized Controlled Trial. Am J Sports Med. 2020 Dec;48(14):3610-3619. doi: 10.1177/0363546520969205. Epub 2020 Nov 6. PMID: 33156692.

TIBERIO, David. The effect of excessive subtalar joint pronation on patellofemoral mechanics: a theoretical model. Journal of Orthopaedic \& Sports Physical Therapy, [S. l.], v. 9, n. 4, p. 160-165, 1987.

VENKADESAN, Madhusudhan; YAWAR, Ali; ENG, Carolyn M.; DIAS, Marcelo A.; SINGH, Dhiraj K.; TOMMASINI, Steven M.; HAIMS, Andrew H.; BANDI, Mahesh M.; MANDRE, Shreyas. Stiffness of the human foot and evolution of the transverse arch. Nature, [S. l.], v. 579, n. 7797, p. 97-100, 2020. DOI: 10.1038/s41586-020-2053-y. Disponível em: http://dx.doi.org/10.1038/s41586-020-2053-y.

WELTE, Lauren; KELLY, Luke A.; LICHTWARK, Glen A.; RAINBOW, Michael J. Influence of the windlass mechanism on arch-spring mechanics during dynamic foot arch deformation. Journal of the Royal Society Interface, [S. l.], v. 15, n. 145, 2018. DOI: 10.1098/rsif.2018.0270.

WITVROUW, Erik et al. Patellofemoral pain: Consensus statement from the 3rd International Patellofemoral Pain Research Retreat held in Vancouver, September 2013. British Journal of Sports Medicine, [S. l.], v. 48, n. 6, p. 411-414, 2014. DOI: 10.1136/bjsports-2014-093450.

YAMAUCHI, Junichiro; KOYAMA, Keiji. Importance of toe flexor strength in vertical jump performance. Journal of Biomechanics, [S. l.], v. 104, p. 109719, 2020. DOI: 10.1016/j.jbiomech.2020.109719. Disponível em: https://doi.org/10.1016/j.jbiomech.2020.109719. 


\section{APÊNDICES}

Apêndice A - Parecer do Comitê de Ética

USP - ESCOLA DE EDUCAÇÃO
FíSICA E ESPORTE DE
RIBEIRÃO PRETO DA USP

PARECER CONSUBSTANCIADO DO CEP

\section{DADOS DO PROJETO DE PESQUISA}

Título da Pesquisa:Mobilidade, força e cinemática do pé em corredores assintomáticos e com Síndrome da Dor Femoropatelar: um estudo transversal.

Pesquisador: Paulo Roberto Pereira Santiago

Área Temática:

Versão: 4

CAAE: 04404918.7 .0000 .5659

Instituição Proponente: UNIVERSIDADE DE SAO PAULO

Patrocinador Principal: Financiamento Próprio

\section{DADOS DO PARECER}

Número do Parecer: 3.673 .409

Apresentação do Projeto:

Vide versão anterior.

Objetivo da Pesquisa:

Vide versão anterior.

Avaliação dos Riscos e Benefícios:

Vide versão anterior.

Comentários e Considerações sobre a Pesquisa:

Vide versão anterior.

Considerações sobre os Termos de apresentação obrigatória:

Vide versão anterior.

Conclusões ou Pendências e Lista de Inadequações:

Não há pendências.

Considerações Finais a critério do CEP:

O projeto encontra-se APROVADO para execução. Pedimos atenção aos seguintes itens:

1) De acordo com a Resolução CNS n. 466/2012, o pesquisador deverá apresentar relatórios semestrais (parciais e final, em função da duração da pesquisa);

Endereço: Avenida Bandeirantes, 3900

Bairro: VILA MONTE ALEGRE

UF: SP MILA MEP: 14.040-907

Telefone: (16)3315-0494

E-mail: cep90@usp.br 


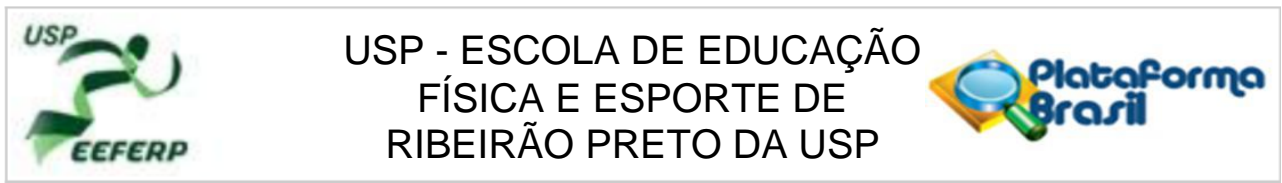

Continuação do Parecer: 3.673 .409

2) Eventuais emendas (modificações) ao protocolo devem ser apresentadas, com justificativa, ao CEP de forma clara e sucinta, identificando a parte do protocolo a ser modificada. Neste caso, o pesquisador deve aguardar nova aprovação do CEP para realizar os procedimentos de acordo com as mudanças solicitadas;

3) Sobre o TCLE: caso o termo tenha DUAS páginas ou mais, lembramos que no momento da sua assinatura, tanto o participante da pesquisa (ou seu representante legal) quanto o pesquisador responsável deverão RUBRICAR todas as folhas, colocando as assinaturas na última página;

4) Caso haja instituição(ões) coparticipante(s) no projeto, atender a solicitação da carta n.ำ 0212/CONEP/CNS, de 21 de outubro de 2010;

5) GARANTIR QUE NOS MOMENTOS DE ATIVIDADE FÍSICA SEMPRE HAJA PELO MENOS UM MEMBRO DA EQUIPE DE PESQUISA APTO A PRESTAR OS SOCORROS DE URGÊNCIA, INCLUSIVE MASSAGEM CARDÍACA E USO DO DEA, CASO NECESSÁRIO.

Este parecer foi elaborado baseado nos documentos abaixo relacionados:

\begin{tabular}{|c|c|c|c|c|}
\hline Tipo Documento & Arquivo & Postagem & Autor & Situação \\
\hline $\begin{array}{l}\text { Informações Básicas } \\
\text { do Projeto }\end{array}$ & $\begin{array}{l}\text { PB_INFORMAÇŌES_BÁSICAS_DO_P } \\
\text { ROJETO_1141968.pdf } \\
\end{array}$ & $\begin{array}{c}31 / 10 / 2019 \\
00: 09: 16 \\
\end{array}$ & & Aceito \\
\hline $\begin{array}{l}\text { Projeto Detalhado / } \\
\text { Brochura } \\
\text { Investigador }\end{array}$ & antonio_30outubro2019_corrigido.pdf & $\begin{array}{c}31 / 10 / 2019 \\
00: 08: 21\end{array}$ & $\begin{array}{l}\text { ANTONIO CARLOS } \\
\text { FERRAZ DE } \\
\text { ANDRADE } \\
\end{array}$ & Aceito \\
\hline Cronograma & cronog_atividades_tabela_out2019iii.pdf & $\begin{array}{c}22 / 10 / 2019 \\
15: 02: 08\end{array}$ & $\begin{array}{l}\text { ANTONIO CARLOS } \\
\text { FERRAZ DE } \\
\text { ANDRADE } \\
\end{array}$ & Aceito \\
\hline $\begin{array}{l}\text { TCLE / Termos de } \\
\text { Assentimento / } \\
\text { Justificativa de } \\
\text { Ausência } \\
\end{array}$ & $\begin{array}{l}\text { TCLE_mod_22_agosto_2019_corrigido. } \\
\text { pdf }\end{array}$ & $\begin{array}{c}21 / 10 / 2019 \\
23: 31: 18\end{array}$ & $\begin{array}{l}\text { ANTONIO CARLOS } \\
\text { FERRAZ DE } \\
\text { ANDRADE }\end{array}$ & Aceito \\
\hline Folha de Rosto & eticarosto_assinada.pdf & $\begin{array}{c}19 / 10 / 2019 \\
16: 45: 22\end{array}$ & $\begin{array}{l}\text { ANTONIO CARLOS } \\
\text { FERRAZ DE } \\
\text { ANDRADE }\end{array}$ & Aceito \\
\hline
\end{tabular}

Endereço: Avenida Bandeirantes, 3900

Bairro: VILA MONTE ALEGRE

UF: SP Município: RIBEIRAO PRETO

Telefone: (16)3315-0494

CEP: $14.040-907$

E-mail: cep90@usp.br 


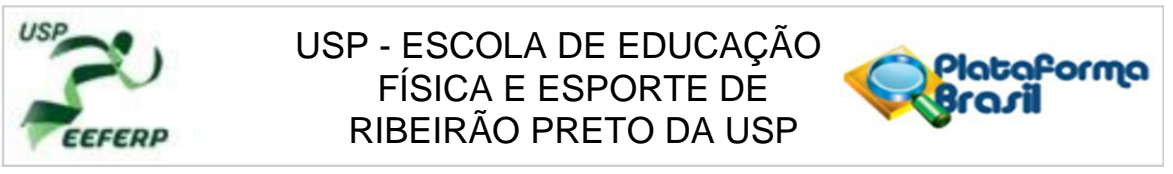

Continuação do Parecer: 3.673.409

Situação do Parecer:

Aprovado

Necessita Apreciação da CONEP:

Não

RIBEIRAO PRETO, 31 de Outubro de 2019

Assinado por:

Carlos Roberto Bueno Júnior

(Coordenador(a))

Endereço: Avenida Bandeirantes, 3900

Bairro: VILA MONTE ALEGRE

CEP: $14.040-907$

UF: SP Municipio: RIBEIRAO PRETO

Telefone: (16)3315-0494

E-mail: cep90@usp.br

Página 03 de 03 